\title{
Knowledge and use of biocultural diversity by Nahua in the Huasteca region of Hidalgo, Mexico
}

\author{
Tania Vianney Gutiérrez-Santillán ${ }^{1}$, Ángel Moreno-Fuentes², Arturo Sánchez-González² and Gerardo \\ Sánchez-Rojas ${ }^{2^{\star}}$
}

\begin{abstract}
In the Huasteca region, high biological diversity and diverse ethnic groups converge. The implementation of metrics for biocultural diversity was developed based on metrics used in analyzes of biological diversity. We compared the results of the diversity known and used by two communities of Nahuatl origin established in two types of vegetation (Tropical Semi Evergreen Forest [TSEF] and Mountain Cloud Forest [MCF]). The fieldwork was carried out from January 2011 to December 2012; the ethnobiological information was collected combining the methods: percentual and snowball, additional applying as an ethnographic tool: multiple free lists and semi-structured interviews to 125 informants. The ethnobiological information was analyzed by adapting indexes used in the evaluation of biological diversity and multivariate methods. The informants identified 409 ethnospecies for both communities, although they only correspond to 383 biological species, the several taxonomic groups. The TSEF presents a greater richness of species-ethnospecies concerning the MCF. Eleven categories of use were identified, with the edible category being the most mentioned. In general, local people have extensive knowledge of the biological diversity present in their territory, and there are distinct differences in knowledge between communities established in different ecosystems. However, there is much similarity in knowledge and use of biodiversity, since both populations belong to the same cultural group. We believe that our results show the relevance of using the metrics used in the evaluation of biocultural diversity.
\end{abstract}

Keywords: Index of Biodiversity; Multitaxonomic; Ethnobiology

1 Instituto de Ecología Aplicada, Universidad Autónoma de Tamaulipas, Av. División del Golfo \#356. Col. Libertad. C.P: 87020, Ciudad Victoria Tamaulipas, México.

2 Centro de Investigaciones Biológicas, Universidad Autónoma del Estado de Hidalgo, Apartado Postal 1-69, Plaza Juárez, C.P. 42001, Pachuca Hidalgo, México.

*Corresponding author. [ E-mail address: TVGS (tvgutierrez_santillan@yahoo.com), AMF (amoreno@uaeh.edu.mx), ASG (arturosg@uaeh.edu.mx), GSR (gsanchez@uaeh.edu.mx)

\section{INTRODUCTION}

A spatial co-occurrence among biological, ecological, environmental, geographical, linguistic and cultural components can be observed around the world; this cooccurrence show that indigenous groups mostly populate greatest biodiversity areas, this correlation is conceptualized as biocultural diversity (Maffi 2001; 2005; 2007; Loh and Harmon 2005; Harmon and Loh 2010; Stepp et al. 2004; 2005). This biocultural diversity establishes unique social-ecological relationships (Pretty et al. 
2009); since it is recognized that each indigenous group appropriates the biodiversity present in their territories (Boege 2008; Toledo 2010).

Although biocultural diversity is recognized, there are semantic and conceptual gaps in the definition, additionally it has been seen that biological diversity and biocultural diversity are not entirely congruent in terms of the factors that generate them (Cardillo et al. 2015). A concept of biocultural diversity should be based on more than merely the sum of its components. For this reason, we contextualize biocultural diversity as "the variety of organisms that are known, named, classified, organized, used, exploited, domesticated and/or manipulated by different human societies; including the social-ecological systems of which this diversity forms a part at various spatiotemporal scales (Gutiérrez-Santillan 2018).

This conceptualization requires us to define the units that make up biocultural diversity, which are called ethnospecies. An ethnospecies corresponds to a biological species and its cultural identity. Indispensable attributes of an ethnospecies are the combination of the taxa itself (species or genus but not any higher category) with the cultural identity associated with the traditional unique name for that taxa as the cognitive basis for the recognition of the organism by human groups (Hunn 2011).

Assessing the richness and diversity known and exploited by human groups, that is, biocultural diversity, helps us to understand the degree of correlation with biodiversity and thus to evaluate other associated phenomena; for example; understand the spatial congruence between species richness and cultural evolution (Turvey and Pettorelli 2014) as well as the loss of both diversities (Sutherland 2003). The importance of maintaining the balance between nature-culture and how to sustain it is related to the proper development of future projects (Maffi and Woodley 2008), the use of natural resources as a way of connecting with nature (Grasser et al. 2012), the conservation of biocultural diversity as a goal (Hong 2013) and even as a response to the challenges faced by large cities (Elands et al. 2018).

Biocultural diversity should be used when designing priorities in conservation (Dunn 2008), and social-ecological research should be the link between human and natural aspects (Gavin et al. 2015; SaslisLagoudakis and Clarke 2013); integrating the new biocultural perspective into conservation biology (Gavin et al. 2015; Gorenflo et al. 2012; Huntington 2013; Luque and Doode 2010; Saslis-Lagoudakis and Clarke 2013; Wolverton et al. 2014). This is supported by successful conservation programs that integrate traditional knowledge and local practices (Huntington 2013; Maffi and Dilts 2014).

Mexico is one of the countries with high biological diversity (Neyra-González and Durand-Smith 1998), as well as cultural diversity (De Ávila 2008), which makes it one of the most propitious countries for ethnobiological research, from different approaches and themes, for example, the traditional classification (Berlin 1973; Berlin et al. 1973; Hunn 1998; 2008; AlcántaraSalinas et al. 2013), the evaluation of cultural importance (Garibay-Orijel et al. 2007). ), the domestication of plants (Bye and Linares 1983), among many other examples. However, few studies comprehensively address the traditional knowledge of different taxonomic groups (Aldasoro-Maya 2012; Argueta-Villamar 2008; Cano 1988; Hunn 1998, 2008). 
Because in general ethnobiological works have been developed by defined subdisciplines (ethnobotany, ethnomycology, and ethnozoology).

The Huasteca is a region located in central-eastern Mexico, where the territories of several indigenous peoples converge. It is characterized by high biological diversity (Olivier 2008; Ruvalcaba et al. 2004), associated to many different geographic and environmental condition. Various ethnobiological studies have been carried out in this region, focusing mainly on ethnobotany of the Teneek (Alcorn 1981a; 1981b; 1983; 1984), Nahuas (Andrade-Cetto 2009; Hernández 2003), Pames (CarbajalEsquivel et al. 2012; Torres et al. 2015), Tepehuas (Álvarez 2002; López-Villafranco and Aguilar-Contreras 2010) and Totonacos (Cano 1988). A number of studies have examined the importance of the socialecological relationship in terms of magical/religious aspects (Montoya 1968; Gallardo-Arias 2004; Piotrowska 2013a; 2013b), traditional medicine (Andrade-Cetto 2009) and the use of edible fungi (BautistaNava 2007; Isidoro-Reséndiz 2011).

The few ethnozoological studies in the region have documented knowledge, perception, classification and, zootherapy. The vertebrate groups studied were fish (Montaño et al. 2010; González et al. 2010), reptiles (Penguilly et al. 2010) and birds (Jaimes et al. 2014). Additionally, research in the Huasteca region has integrated ethnobiological data for multiple taxonomic groups; for example, in Hidalgo (GutiérrezSantillán 2013; Hernández and Bautista 2011), in Puebla (López del Toro et al. 2009), in San Luis Potosí (Alonso-Castro et al. 2011) and Veracruz (Cano 1988), which has contributed to recognition of the biocultural diversity of the region.
Considering that the Huasteca region is rich in biodiversity and has the presence of one of the most representative ethnic groups in Mexico the Nahuas, the work is approached as a case study on conceptual and methodological aspects of cultural diversity. We proposed the use of the most current metrics for the analysis of biological biodiversity, to propose it as a new approach to the measurement of biocultural diversity. The I study was designed with the following objectives: 1) to identify the ethnospecies of plants, fungi, and animals that the local people know and use, in order to document their degree of knowledge about local biodiversity; 2) to compare ethnospecies richness between the different vegetation types, in order to find out whether traditional knowledge is similar within a given cultural group or whether it may differ between different ecosystems; 3 ) to analyze the ethnospecies detected in the study by means of diversity indexes as an evaluation metric for use in biocultural diversity studies; 4) to evaluate the degree of correlation between taxonomic species and ethnospecies, in order to find the degree of culturally recognized biodiversity; and 5) to identify use categories, in order to find the association between taxonomic groups and use categories.

We expected to contribute to the subject of biocultural diversity by establishing ethnospecies as social-ecological units of study and their evaluation by using the most recent biodiversity metrics (Moreno et al. 2017); The study was carried out in two Nahua communities established in different types of vegetation in the Huasteca region in the state of Hidalgo, Mexico. 


\section{MATERIAL AND METHODS}

\section{Study area}

The Huasteca is a region located in central-eastern Mexico that includes portions of the states of Hidalgo, Puebla, Querétaro, San Luis Potosí, Veracruz and Tamaulipas. The majority of the inhabitants of the Huasteca region are mestizos, but a number of native peoples share the territory; Nahuas, Huastecos, Pames, Otomíes, Tepehuas and Totonacos (Olivier 2008).

The present study involves Nahuas, as they are one of the most numerous indigenous peoples and among the most widely distributed in Mexico. In the Huasteca, Nahuas live in more than 50 municipalities (county equivalents) in the states of Hidalgo, San Luis Potosí, and Veracruz (INALI 2008). In the state of Hidalgo, they live in 13 municipalities in the northeast as well as a small group in the southwest (Báez et al. 2012). The Huasteca part of Hidalgo state mainly contains two types of vegetation; tropical semi-evergreen forest (TSEF) and montane cloud forest (MCF), the TSEF covering more area than the MCF (Puig 1991). In addition, there are extensive areas of farmland, both crop and livestock. The main crops are corn, coffee, beans, sugar cane and oranges (Barthas 1996).

The study areas were selected using the criteria 1) ethnic identity, 2) more than $80 \%$ indigenous language speakers, and 3) low disturbance of the vegetative cover. This approach allows a selection of study sites associated conditions of research interest and not a priori selection assigned by the investigator (Gutiérrez-Santillan et al. 2019a). Two communities were selected: a) El Barco, in the municipality of Lolotla $\left(21^{\circ} 10^{\prime} 45.33^{\prime \prime} \quad\right.$ - 21ำ'32.89" N,
98 $43^{\prime} 26.58^{\prime \prime}$ - 9843'13.90" W; 140 masl; vegetation type TSEF, annual temperature: $18^{\circ} \mathrm{C}$ to $25^{\circ} \mathrm{C}$, annual precipitation: 1600-1900 mm; with a populations of 380 inhabitants (INEGI 2010). In this community, the main activity is agriculture, to lesser extent livestock and fishing as a recreational activity. Some informants mentioned working in the citrus groves near the community; Figure 1); b) Tlamamala, in the municipality of Huazalingo $\left(20^{\circ} 58^{\prime} 15.27^{\prime \prime}-20^{\circ} 58^{\prime} 0.64^{\prime \prime} \mathrm{N}\right.$ and $98^{\circ} 32^{\prime} 40.45^{\prime \prime}-98^{\circ} 32^{\prime} 21.34 ", 960$ masl, vegetation type MCF, annual temperature: $13^{\circ} \mathrm{C}$ to $21^{\circ} \mathrm{C}$, annual precipitation 1500-2800 mm; with a population of 750 inhabitants (INEGI 2010; Figure 1). The main activity is family farming, coffee harvest (coffee under shade) and livestock. Some of the informants mentioned working in the nearby city of Huejutla de Reyes, Hidalgo (approximately $40 \mathrm{~km}$ ), and even in other cities of the country.

\section{Fieldwork}

Before fieldwork commenced, the study proposal was submitted to local authorities and approved by a community assembly (International Society of Ethnobiology 2006; http://ethnobiology.net/code-of-ethics/). At each interview, consent was obtained from the informant, including consent for photography and participant observation (Albuquerque et al. 2014). The field research was carried out during a two-year period from January 2011 to December 2012, with a total of 20 visits to each of the two locations.

Ethnobiological data were obtained by combining the ethnographic percentage method $(10 \%$ of the population; Bernard 2006) and the snowball technique (Brewer 1995; 2002; Trotter et al. 2001). The combination of both methods allowed us to 


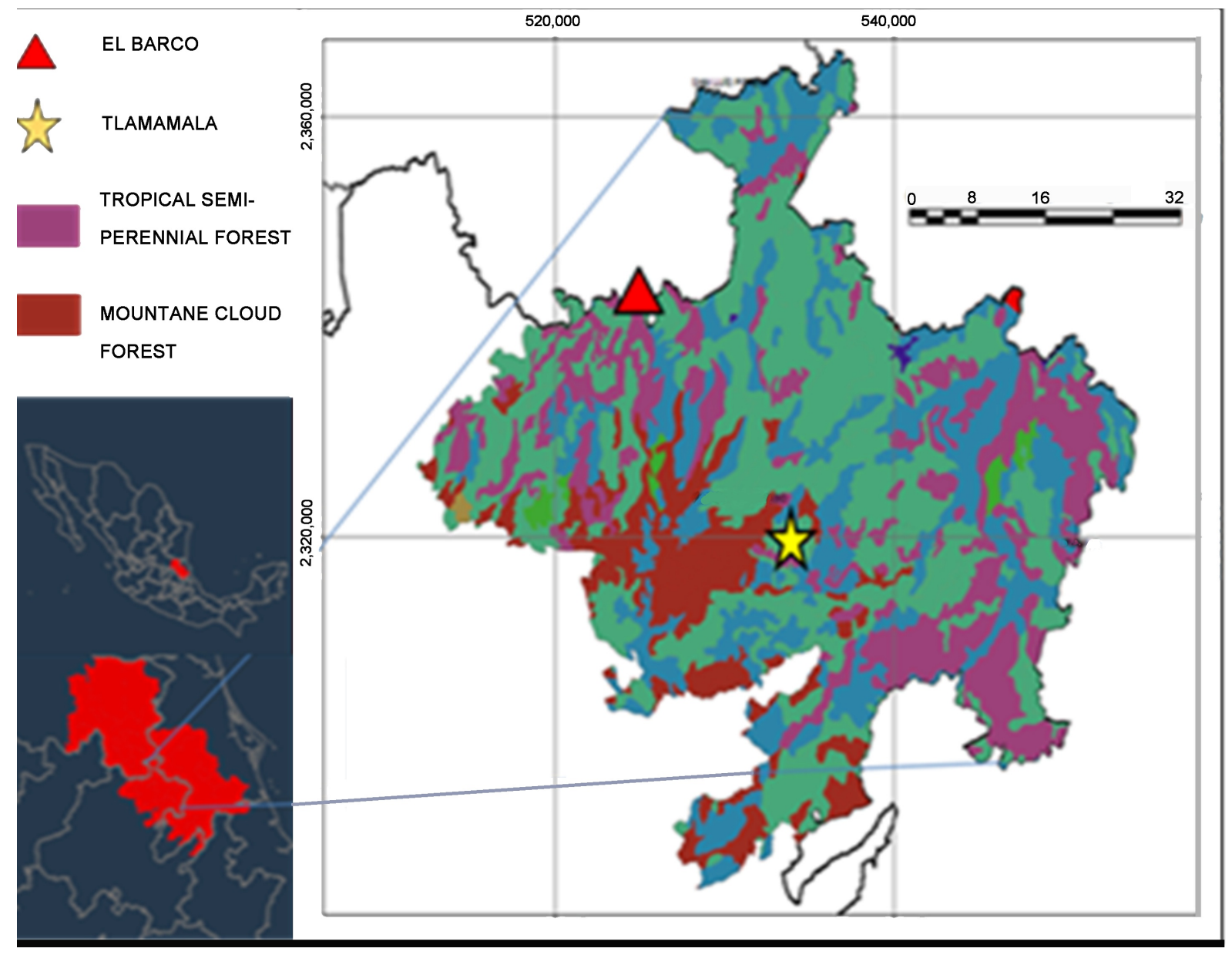

Figure 1. Location of study sites. The red zone on the left represents the Huasteca portion of the state of Hidalgo, Mexico. The triangle shows the location of El Barco (TSEF $=$ tropical semi-evergreen forest, 140 masl) and the star shows the location of Tlamamala (MCF = montane cloud forest, 960 masl).

work with an ethnographic sample determined by chance, having informants in general and not only expert informants. During the development of the interviews in many of the cases, the same informant was interviewed several times. Also, it should be noted that no additional ethnographic data were obtained; only sex, age and yes, his mother tongue was Nahuatl.

A total, 125 interview combinations were applied; a) 50 informants in the town of El Barco of whom $50 \%$ were women and $50 \%$ men, with age between 21 and 72 years and $94 \%$ are speakers of the indigenous language. B) 75 informants in the locality of Tlamamala of which $38 \%$ were women and
$62 \%$ men, with ages between 20 and 84 years, and $88 \%$ are speakers of the indigenous language.

Ethnographic tools were also used by combining: multiple free listings (Brewer 1995; 2002) and semi-structured interviews (Bernard 2006; Albuquerque et al. 2014). First, informants were asked about plants, fungi, and animals are known in the area (multiple free listing in Spanish and Nahuatl); Later using the semi-structured interview, the use of the referred ethnospecies was asked. The interview data organized in databases, for a) plants, b) and c fungi) animals, is organized by last taxonomic group (fish, amphibians/reptiles, birds and mammals). 
Each database consisted of several sets of information: a) information the informant (name, gender, age, indigenous language speakers), b) taxonomic data (order, family, genus, species), c) nomenclature traditional (name in Nahuatl and Spanish) and d) category of use.

\section{Collection, identification material \\ processing and of ethnobiological}

The biological material was processed and identified according to the taxonomic group in general; they had a) collections of fungi and plant specimens were collected in the field during the trips with the inhabitants to their daily activities (participative observation; Bernard 2006). The collections were processed and dehydrated adequately, later in the laboratory they were identified with the use of taxonomic keys. Fungal specimens are deposited in the collection ethnomycology "Dr. Teófilo Herrera Suárez" at the Center for Biological Research, the Autonomous University of the State of Hidalgo, Mexico. The deposit of the plants was not possible in an official collection because you do not have an herbarium of ethnobotany.

For different groups of animals fieldwork was based primarily on: b) animals or parts of animals donated by the informants; $c$ ) photographs of animals or parts of animals; d) visual stimuli - pictures based on the design of posters of species already reported in the region (Bernard 2006; Albuquerque et al. 2014), and e) field guides, e.g., birding guides (Albuquerque et al. 2014). In general, for all taxonomic groups, it has been made f) traditional nomenclature associated (documented by us) with bibliographic ethnobiological information for the region; and $g$ ) the association of the species (identified by us) concerning published regional taxonomic lists.

Species were identified to the lowest possible taxonomic level, based on the respective literature for the group; fungi (Bautista-Nava 2007; Isidoro-Reséndiz 2011), plants (Andrade-Cetto 2009; Luna et al. 1994; Pennington and Sarukhán 2005; Pérez-Escandón et al. 2003; Puig 1991; Villavicencio 2005; Villaseñor 2016), crustaceans (Álvarez et al. 2012), mollusks (Correa-Sandoval 2003), millipedes (Bueno 2012) and vertebrates (fish: González et al. 2010; Miller 2009; amphibians and reptiles: Ramírez-Bautista et al. 2014; birds: Howell and Webb 1995; Peterson and Chalif 2000; Martínez-Morales 2007; Martínez-Morales et al. 2007; and mammals: Ceballos and Oliva 2005).

In addition, lists of species reported for the respective taxonomic groups in the Huasteca Hidalguense were used (RamírezBautista et al. 2017). In the MCF, 336 species of plants have been recorded (Luna et al. 1994), 181 bird species (MartínezMorales 2007), 34 mammal species (Mejenes-López 2008; Mejenes-López et al. 2010), 73 amphibian and reptile species (Ramírez-Bautista et al. 2014), and 22 species of fish (González-Rodríguez et al. 2010). For the TSEF, 274 species of plants have been recorded (Puig 1991; Villavicencio 2005; Villaseñor 2016), 173 bird species (Martínez-Morales et al. 2007), 35 mammal species (Mejenes-López 2008; Mejenes-López et al. 2010), 32 amphibian and reptile species (Ramírez-Bautista et al. 2014) and 28 species of fish (GonzálezRodríguez et al. 2010).

The categories of use were established through the use reported by informant (emic categories for region) additionally other proposals in the literature were consulted 
(Farfán et al. 2007; Lira et al. 2009; MonroyVilchis et al. 2008). Eleven categories were identified: ceremonial, fuel, edible, construction, timber, pets, medicinal, ornamental, commercial/sale, agricultural use and other (which contained any other uses which were mentioned only once in the interviews).

\section{Data analysis}

The inventory of biocultural diversity was measured by means of indexes adapted from metrics used to analyze biological diversity. To determine whether the number of selected informants was sufficient to obtain a complete inventory of known and exploited diversity (frequency of mention, FM), an accumulation curve was plotted using the non-parametric first-order Chao index (Chao1), calculated by means of the Estimates 8.0 program (Corwell et al. 2004). The Chao1 estimator is a method that uses abundance data and is based on the number of species that occur only once or in one sample and the number of species that occur exactly twice or in two samples (Escalante 2003).

In this case, the abundance data of the species in a sample was replaced by FM data; that is, the number of times a species $i$ is mentioned in a sample (Pineda and Verdú 2013). An approximation of the expected number of ethnospecies was calculated, to estimate whether the number of interviewees (sampling effort) was sufficient for a complete inventory. Nonparametric estimators have their statistical basis in techniques for estimating the number of classes from samples and capture-recapture techniques (Chao and Lee 1992; Jiménez-Valverde 2003). In the present case, this corresponds to informants-mentioned considering each interviewee as a sampling unit. An assumption of these nonparametric estimators is that the probability of capture here the probability that an ethnospecies is mentioned - must remain constant throughout the period of ethnographic sampling.

The analysis of biocultural diversity was calculated based on the diversity formula proposed by Jost (2006), which is known as a zero-order and first-order measure of diversity (Hill 1973), using the formula:

$$
{ }^{q} D=\left(\sum_{i=1}^{s} p_{i}^{q}\right)^{\frac{1}{(1-q)}}
$$

where $p_{i}$ is the abundance of species $i$ divided by the total sum of the abundances of the $S$ (species), and the exponent $q$ is the order of diversity. The order of diversity $(q)$ is influenced by the relative abundance of the species in the index; that is, the predominance of common species or of rare species. In the present case, the relative abundance values in the ecological inventories are replaced by the values obtained for the FM of the reported ethnospecies.

Zero-order ( $\left.{ }^{0} \mathrm{D}\right)$ and first-order ( $\left.{ }^{1} \mathrm{D}\right)$ diversity values were calculated. Zero-order diversity $\left({ }^{0} \mathrm{D}\right)$ is based on the number of incidences of the species in the sample, which is equivalent to species richness, or in our case ethnospecies richness. In firstorder diversity $\left({ }^{1} \mathrm{D}\right)$, all the species in a sample are aggregated with a value exactly proportional to their relative abundance, without overvaluing the rare or common species (Hill 1973; Jost 2006; Moreno et al. 2011; Moreno et al. 2017). First-order diversity $\left({ }^{1} \mathrm{D}\right)$ can be interpreted as the number of effective species, these being understood as units corresponding to the 
numbers of species with the abundances that would theoretically coexist in a community with maximum equality (Moreno et al. 2017). Using this index facilitates comparing the numbers of species between communities and quantifying the differences between them (Hill 1973; Jost 2006; Moreno et al. 2011).

To compare the sites in terms of ethnospecies composition, the Sørensen similarity index $\left(I_{s}\right)$ was used. The degree of association between the species recorded in the literature for the region (independent variable) and the ethnospecies reported in this study (response variable) was tested by linear correlation using the Past 3.20 program (Hammer et al. 2001).

In order to describe the association between use categories and biological groups, a correspondence analysis (CA) was carried out in the Statistica program (StatSoft 2004). A data matrix was created, where the variables correspond to biological groups and the cases to use categories. The chi-square statistic $\left(X^{2}\right)$ and the percentage of variation explained between the first and second dimensions were calculated.

\section{RESULTS}

\section{Analysis of Biocultural Diversity}

A total of 408 ethnospecies that integrate the biocultural diversity recognized by the Nahuas of the Huasteca region in the state of Hidalgo were recorded. These correspond to 383 species distributed in 343 genera belonging to 160 families (Supplementary Material). The biological groups recorded overall were plants $(59 \%)$, birds $(16 \%)$, mammals $(9 \%)$, fish $(8 \%)$, amphibians and reptiles $(5 \%)$, fungi $(3 \%)$, and invertebrates (molluscs, crustaceans and millipedes $>1 \%$ ). The biological group with the most recorded taxonomic families was plants $(58 \%)$, followed by birds $(16 \%)$ and mammals $(9 \%)$ (Table 1). In addition, 342 ethnospecies were mentioned in some use category; 304 species used in the TSEF and 290 species used in the MCF, a difference of 14 .

The ethnospecies accumulation curves for the TSEF showed that $82 \%$ of the expected ethnospecies were represented (Chao1 = 291), and for the MCF, $79 \%$ were

Table 1. Species-ethnospecies data for biological groups listed by inhabitants of two Nahua communities in the state of Hidalgo, Mexico. There was a strong relationship overall between the species and their cultural counterparts (ethnospecies); however, in the case of invertebrates, taxonomic identification was only made to the level of gender and family. TSEF $=$ tropical semievergreen, MCF montane cloud forest.

\begin{tabular}{c|c|c|c|c}
\hline Biological group & $\begin{array}{c}\text { Number of } \\
\text { families }\end{array}$ & $\begin{array}{c}\text { Total } \\
\text { number of } \\
\text { species }\end{array}$ & $\begin{array}{c}\text { Number of } \\
\text { ethnospecies } \\
\text { TSEF }\end{array}$ & $\begin{array}{c}\text { Number of } \\
\text { ethnospecies } \\
\text { MCF }\end{array}$ \\
\hline Invertebrates & 2 & 0 & 2 & 2 \\
\hline Fish & 10 & 31 & 24 & 8 \\
\hline $\begin{array}{c}\text { Amphibians \& } \\
\text { Reptiles }\end{array}$ & 10 & 21 & 22 & 43 \\
\hline Birds & 27 & 61 & 57 & 34 \\
\hline Mammals & 17 & 34 & 31 & 8 \\
\hline Fungi & 7 & 13 & 12 & 199 \\
\hline Plants & 87 & 223 & 207 & $\mathbf{3 0 8}$ \\
\hline TOTAL & $\mathbf{1 6 0}$ & $\mathbf{3 8 3}$ & $\mathbf{3 5 5}$ & 44 \\
\hline
\end{tabular}


represented $($ Chao1 $=275)$. In both cases, the actual ethnographic sampling effort (number of interviews) is located in the asymptote of the curve, which suggests that the inventory of known and used biodiversity was very few interviews short of a complete inventory (Figure 2).

For the TSEF, zero-order diversity ( $\left.{ }^{0} \mathrm{D}\right)$ was 355 ethnospecies (invertebrates 2, fish 24 , amphibians and reptiles 22, birds 57 , mammals 31, fungi 12 and plants 207) and first-order diversity $\left({ }^{1} \mathrm{D}\right)$ was 234.2 ethnospecies (invertebrates 1.9, fish 21.5, amphibians and reptiles 19.9, birds 44.7, mammals 23.7, fungi 9.9 and plants 136.7). For the MCF, the ${ }^{0} \mathrm{D}$ was 308 ethnospecies (invertebrates 2, fish 8 , amphibians and reptiles 13 , birds 44 , mammals 34 , fungi 8 and plants 199) and ${ }^{1} D$ was 202.3 ethnospecies (invertebrates 1.8, fish 6, amphibians and reptiles 8.6 , birds 31 , mammals 23.5, fungi 5.8 and plants 131). The observed difference between the TSEF and the MCF was 47 ethnospecies for ${ }^{0} \mathrm{D}$ and 31.95 ethnospecies for ${ }^{1} \mathrm{D}$ (Figure 3 ).

We found a similar composition of known and used ethnospecies in the two Nahua communities even though they are in

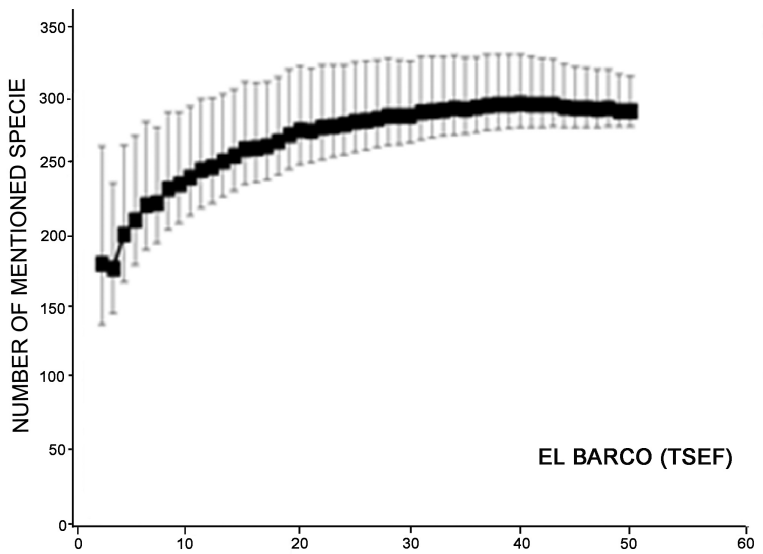

different vegetation types. The Sørensen similarity between the TSEF and the MCF was $84 \%$, indicating that a large percentage of ethnospecies are shared between the two sites. In addition, a positive correlation was found between the number of species reported in the literature for the different taxonomic groups and the number of ethnospecies documented in the present study ( $r=0.8424, p=0.0037)$. This indicates that most species have their cultural counterpart and that much of the knowledge about biodiversity is shared, independently of vegetation type, a phenomenon associated with the cultural origin of the human group and the fact that both communities are in the same geographical region.

\section{Use Trends}

A total of 11 use categories were identified for both communities. The categories containing the highest number of ethnospecies are commercial trade or sale $(28.7 \%)$, edible uses $(17.5 \%)$ and medicinal uses $(14.1 \%)$; followed by the categories with moderate values: ornamental $(11.1 \%)$,

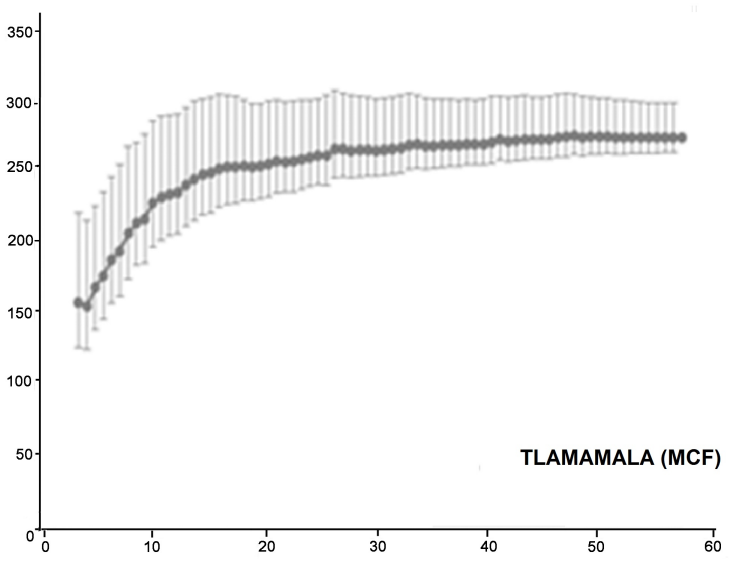

NUMBER OF INFORMANTS

Figure 2. Accumulation ethnospecies curve based on the number of interviews and the nonparametric Chao first-order accumulation function (Chao1). On the x-axis, the number of informants is shown by community, while the $y$-axis shows the cumulative number of mentioned species (FM). The bars at each point represent the $95 \%$ confidence interval. TSEF $=$ tropical semi-evergreen, MCF $=$ montane cloud forest. 


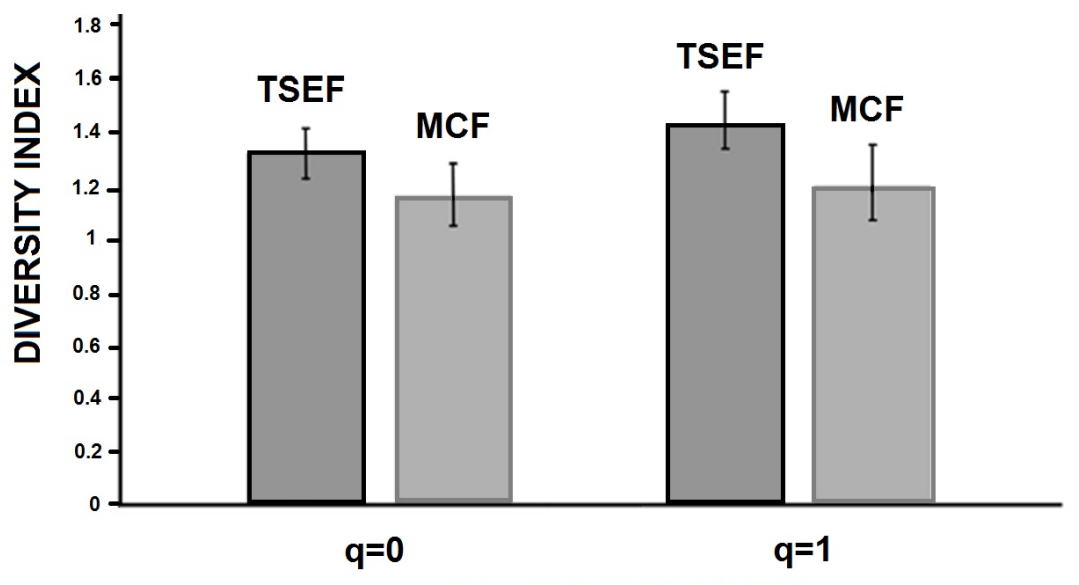

LEVELS OF DIVERSITY

Figure 3. Diversity values of order zero (OD) and first order (1D) by vegetation type. To graph the values, the Shannon index was used in both levels of diversity. The data were the number of ethnospecies by biological group for zero-order diversity and the inverse of the Shannon index for first-order diversity. This procedure enabled the confidence intervals to be obtained. TSEF $=$ tropical semi-evergreen, $\mathrm{MCF}=$ montane cloud forest.

fuel $(6.3 \%)$ and pets $(5.3 \%)$. The categories with the lowest values are ceremonial and construction with $4.5 \%$ each, timber $(2.0 \%)$ and agricultural use (1.8\%). Four of the categories (fuel, construction, timber, agricultural use) only contained plant species, and the pet category was exclusive to animals, mainly birds and mammals (Table 2).

The correspondence analysis (CA) showed the association between biological groups and anthropocentric categories, including ethnospecies that are used in different ways in the two communities. There is a significant relationship between biological group and use category $\left(x^{2}=\right.$ 537.35, $d f=50, p<0.05)$. The two dimensions explain $81 \%$ of the variation in the data. In the first dimension, plants contribute the most to the variance (eigenvalue $=-0.4621$ ), followed by birds (eigenvalue $=0.2648$ ) and mammals (eigenvalue $=0.1520) . \quad$ In the second dimension, the main contributions to the variance are from fish (eigenvalue= -0.1816 ), fungi (eigenvalue $=-0.0570$ ) and amphibians and reptiles (eigenvalue= 0.0330).
We can observe in the graph (Figure 4) that certain categories of use are exclusive of certain biological groups. For example, the categories of agricultural uses, fuel, construction, and wood are exclusive to the plants; while the pet category with birds, mammals and reptiles. In turn, birds and mammals are more related to ornamental use and as pets, while reptiles with ceremonial uses. Some generic categories are more associated with vertebrates than with plants (e.g., ornamental and ceremonial), or, for example, the edible category (which should be generic) has a more significant relationship for fungi and fish; this is due to the fact that the ethnospecies that form these two biological groups generally only fulfill alimentary functions (Figure 4). The association of the biological groups and the categories of use, in this case, is given by the frequency of mention of each one of the ethnospecies for each one of the categories; so, the relationship shown in the chart (Figure 4) is specific for these two study communities. 
Table 2. Relationship between number of ethnospecies mentioned and categories of use. Plants are the group with greatest diversity of categories, invertebrates and fish are the group with the least.

\begin{tabular}{|c|c|c|c|c|c|c|c|c|c|c|c|}
\hline $\begin{array}{l}\text { Biological } \\
\text { group }\end{array}$ & 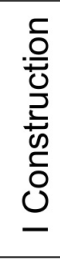 & $\begin{array}{l}\bar{\Phi} \\
\stackrel{\varrho}{E} \\
= \\
= \\
=\end{array}$ & 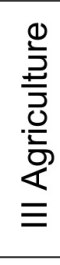 & $\begin{array}{l}\bar{\Phi} \\
\stackrel{1}{\overrightarrow{1}} \\
\geq\end{array}$ & 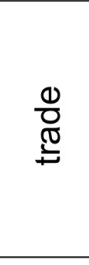 & $\begin{array}{l}\frac{\infty}{d} \\
\frac{\infty}{5} \\
\frac{0}{>}\end{array}$ & 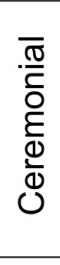 & 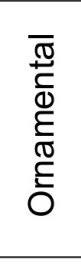 & 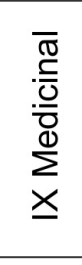 & $\begin{array}{l}\frac{n}{0} \\
\frac{0}{x}\end{array}$ & $\begin{array}{l}\bar{\Phi} \\
\overline{\bar{\nu}} \\
\bar{x} \\
\bar{x}\end{array}$ \\
\hline Invertebrates & & & & & & & & & 2 & & 3 \\
\hline Fish & & & & & & & & 2 & 11 & & 31 \\
\hline $\begin{array}{l}\text { Amphibians } \\
\& \\
\text { Reptiles }\end{array}$ & & & & & & 8 & 4 & & 7 & 3 & 2 \\
\hline Birds & & & & & 25 & 1 & 17 & 37 & 32 & 29 & 16 \\
\hline Mammals & & & & & 20 & 4 & 4 & 27 & 20 & 17 & 21 \\
\hline Fungi & & & & & 6 & & & & & & 11 \\
\hline Plants & 42 & 19 & 17 & 58 & 236 & 21 & 17 & 36 & 58 & & 77 \\
\hline Total & 42 & 19 & 17 & 58 & 287 & 34 & 42 & 102 & 130 & 49 & 161 \\
\hline
\end{tabular}

Legend: Relationship between number of ethnospecies mentioned and categories of use. Plants are the group with greatest diversity of categories, invertebrates and fish are the group with the least.

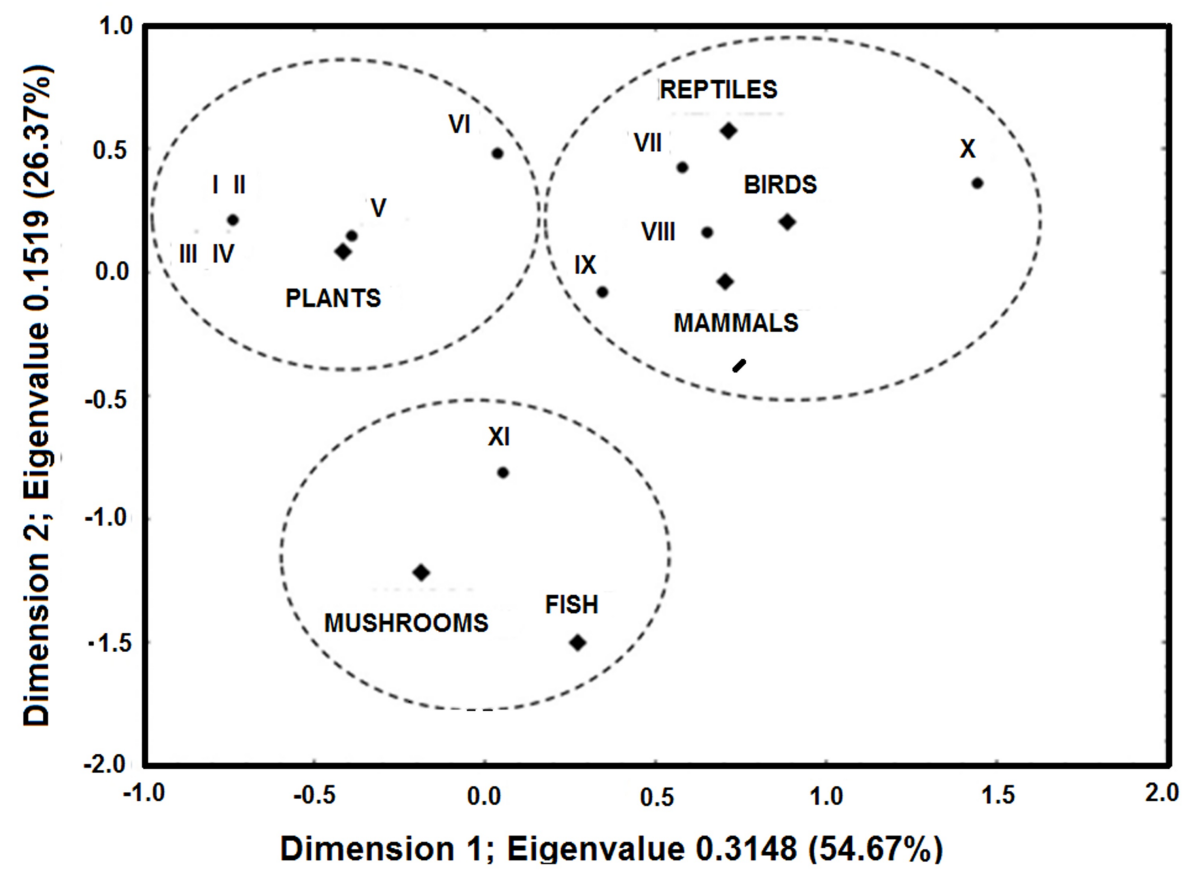

Figure 4. The correspondence analysis shows the association between the biological groups; mammals, birds, reptiles, fish, fungi and plants, with respect to the use categories: I= construction, II= timber, III= agricultural use, IV= fuel, V= sale or commercial trade, VI= others, VII= ceremonial, VIII= ornamental, $\mathrm{IX}=$ medicinal, $\mathrm{X}=$ pets, and $\mathrm{XI}=$ edible. In some cases, a specific relationship is observed between biological groups and certain categories; for example, fish and fungi are associated with the edible category because fungi are normally only harvested for food, and fish can only be sold sometimes, so their main use is as food. In contrast, mammals, birds and reptiles are mostly related to ceremonial, medicinal, ornamental and pet uses, while plants are associated with uses such as timber, agriculture, construction, fuel and commercial use. 


\section{DISCUSSION}

\section{Biocultural diversity of the Nahua}

The Nahuas of the Huasteca region in Hidalgo state have extensive knowledge about the biodiversity in their environment. In this study, 408 ethnospecies were reported. They are associated with 383 species belonging to a variety of biological groups (invertebrates, amphibians and reptiles, fish, birds, mammals, fungi and plants). This is a higher number of ethnospecies than were found by other comparable ethnobiological studies (Caballero and Mapes 1985; Farfán et al. 2007; Nabhan et al. 1982). Other studies have generally not addressed all three main ethnobiological subdisciplines; ethnomycology, ethnobotany and ethnozoology. Our research is a contribution from a comprehensive ethnobiology perspective, combining the three subdisciplines integrating various biological groups and evaluating social-ecological biodiversity knowledge held by a specific indigenous group. In addition, this study contributes to the analysis of biocultural diversity by treating ethnospecies as units of analysis, as has been done in ecology (Moreno 2011; Moreno et al. 2017) and shows how metrics used in the analysis of biological diversity can be adapted to the analysis of biocultural diversity.

Comprehensive ethnobiology research has been previously addressed by Toledo et al. (1983) who documented 410 species for the Pu'rhépechas, Hunn (2008) who recorded a total of 1,379 species (fungi, plants, invertebrates and vertebrates) known and used by the Zapotecs, and AldasoroMaya (2012) who reported 264 species known and used by the the Tlahuica. However, there are few such ethnobiology studies using a comprehensive approach, for reasons such as lack of availability of time, funding, access to communities, or lack of transdisciplinarity, among others. It is more common to find multitaxonomic research addressing two or three biological groups (Nabhan et al. 1982; Caballero and Mapes 1985; Farfán et al. 2007).

On the other hand, regarding the knowledge and use of biocultural diversity, a high similarity is determined even though the communities are established in two different types of vegetation (TSEF and MCF). The similitude may be given because they share common species, which are generally widely distributed or introduced. It also suggests that this phenomenon is associated with the cultural memory or bio-cultural patrimony of both communities, as it belongs to the same indigenous group (Olivier 2008), as well as geographic proximity (see map). So, when studying two types of dominant vegetation in the Huasteca region (Puig 1999), it is likely that the social-ecological relationships for the Nahuas are similar.

The biocultural diversity reported here indicates a high degree of recognition and use of the natural environment in communities where the traditional language and many of the customs are still preserved. This is confirmed by the significant positive correlation between the number of ethnospecies and the number of species reported in the literature for the various taxonomic groups (Ramírez-Bautista et al. 2017).

\section{Conceptual contribution}

We propose that Biocultural diversity as: "the variety of organisms that are known, named, classified, organized, used, exploited, domesticated and/or manipulated by different human societies; including the social-ecological systems of which this 
diversity forms a part at various spatiotemporal scales (Gutiérrez-Santillan 2018). But this concept also must be referred to the correlation between its biological, ecological, environmental, geographical, cultural and linguistic components; include a regional or global spatial scale (Maffi 2005; 2007; Loh and Harmon 2005; Harmon and Loh 2010; Stepp et al. 2004; 2005; Turvey and Pettorelli 2014). However, in sensu stricto has been seen that biological diversity and biocultural diversity are not entirely congruent in terms of the factors that generate them (Cardillo et al. 2015).

However, the design of a conceptual framework in the metric of cultural diversity analogous to that of biological diversity will not only allow us to understand it, but also to confirm that its identification and evaluation are adequate (Maclaurin and Sterelny 2008). Currently, the existence of biocultural diversity as a real and inherent property of the social-ecological relationship is not discussed, however, semantic, conceptual and analytical gaps are detected; for which different approaches can be useful to generate new research perspectives as in ecology (Moreno et al. 2011).

One of the fundamental bases for the conceptual development of biocultural diversity is the establishment of real and identifiable social-ecological units or entities, as for example in ecology, that operational taxonomic units have been used (Krell 2004). Although ethnobiology has sought to develop research on the knowledge and use of biodiversity, some of the previous studies do not discriminate between species and ethnospecies, or do not consider this criterion as a rule in ethnobiological research; taking both as an independent record or identifiable entity. We consider it essential to establish the units of analysis, referring to the ethnospecies, which must be integrated by the taxonomic identity of the species plus their corresponding culture; this criterion should apply regardless whether the investigation has a qualitative or quantitative approach. In addition, the establishment of ethnospecies as units of analysis, as has been done in ecology (Moreno et al. 2011; Moreno et al. 2017) favors the adaptation of current metrics used in the analysis of biological diversity to the analysis of biocultural diversity.

The identity of the social-ecological units is critical to begin to understand biocultural diversity from a more local and analogous view to biodiversity. Our study allows us to observe another pattern more like those of biological diversity, such as the recognition of common species, as well as rare species (Turner et al. 2011). As examples of common species we have the coyote/coyochichi (Canis latrans), the pigeons/singuilotl (Claravis pretiosa, Leptotila verreauxi, Geotrygon albifacies), the fungus orejita-deviejita/cuapetachiquinte (Auricularia auricula, A. delicata, A. fuscosuccinea), and trees such as guava (Psidium guajava) and framboyán/ framboyánxuchitl (Delonix regia). And as rare species we have the anguila/coatlmichi (Anguilla rostrata), the jaguar/tecuani (Panthera onca) and, the perro-de-agua/atlchich (Lontra longicaudis), these recently reported species for the state of Hidalgo (Aguilar-López et al. 2015; Morales-García and Acosta-Rosales 2015). Or tree species that are very scarce in the surrounding forests, but culturally highly valued as the palo-escrito (Dalbergia paloescrito) or the palo-varón/tlacacuahuitl (Ulmus mexicana). Even the documentation of a locally extinct species was obtained: the mono/chango (Ateles geoffroyi), which is estimated to have been extirpated from northeastern Mexico (Ceballos and Oliva 
2005).

Biocultural diversity is part of the memory or biocultural heritage of indigenous peoples, their documentation, analysis and evaluation; it can be appreciated by biologists of conservation, by documenting traditional knowledge and practices historical and currently conducted on biodiversity, helping to understand changes in local biodiversity and designing appropriate conservation strategies (Brook and McLachlan 2008, Saslis-Lagoudakis and Clarke 2012). In addition, under the perspectives projected in this research, we seek to open a way for conceptualization and the establishment of methodologies that help to understand biocultural diversity from the low level to more complex analyzes, such as, for example, macro-ethnobiological (Gutierrez-Santillán et al. 2019b), the evolutionary ethnobiology (Albuquerque $y$ Ferreira-Junior 2017), the niche construction theory and ethnobiology (Albuquerque et al. 2018); and the development of the socialecological theory of maximization (Albuquerque et al. 2019).

The use of new metrics for the analysis and evaluation of biocultural diversity

The comprehensive analysis of biocultural diversity (multitaxonomic and quantitative) generates a clearer picture of socialecological knowledge. To do so, it is essential to evaluate biocultural diversity using metrics, which give greater robustness to the results and allow for comparisons, as has been done in ecology (Moreno et al. 2017).

It is, of course, important that the theoretical assumptions required for the chosen metrics be met. In this case, we evaluate whether the ethnographic sampling effort is enough using accumulation curves (Alves et al. 2016). The curves showed that the number of interviews was enough for the inventory. This suggests that when the percentage ethnographic method, which generally implies sampling $10 \%$ of the inhabitants of a population (Bernard 2006) is applied in combination with the snowball method (Trotter et al. 2001), it is possible to obtain a robust inventory of ethnobiological information. In addition, selecting informants using the snowball method enables a random sample to be drawn (Trotter et al. 2001). In addition, the combination of ethnographic tools (multiple free lists and semi-structured interviews) also allow an adequate collection of information.

These metrics can be used to corroborate the completeness of the ethnobiological data, since the accumulation curves and estimates of chosen species (nonparametric) are good indicators of the quality of the sample (Albino-García et al. 2011; Benz et al. 2000; Hopkins and Stepp 2012; Lozada et al. 2006; Pineda and Verdú 2013), in our case indicating proper ethnographic sampling.

In the accumulation curves, frequency of mention is used, considering each informant as a sampling unit, and the mentions of ethnospecies represent their cultural importance, not their abundance in nature. In ethnographic sampling there are ethnospecies that are constantly mentioned, or common, and ethnospecies that are mentioned only occasionally or rarely. However, it is important to assess in which cases to apply the accumulation curve or not, since the curve may be indicating that our inventory is close to the optimum; that is, increasing the sampling number maintains the asymptote constant (Alves et al. 2016; Moroy-Vilchis et al. 2008); but other methodological aspects must be adhered to, 
such as ensuring random and homogeneous sampling.

For the implementation of these and other metrics, it is essential to keep in mind that the methods used in the analysis of biological diversity are constantly being updated (Moreno et al. 2011; 2017), making it necessary to evaluate their usefulness in ethnobiological or biocultural diversity studies. For example, the zero-order $\left({ }^{0} \mathrm{D}\right)$ and first-order diversity index $\left({ }^{1} \mathrm{D}\right)$ are in current use (Hill 1973; Jost 2006). The advantage of using these indices is that the results are comparable within a study and with other studies in the same region whether intra- or inter-ethnically; and across time spans to evaluate cultural changes in knowledge or uses; that is, to evaluate local knowledge at different space and time scales (Gutiérrez-Santillán et al. 2019b).

In this study we use only the ${ }^{0} \mathrm{D}$ and ${ }^{1} \mathrm{D}$ diversity indices, because the zero-order diversity data corresponds to species richness, in our case ethnospecies richness, while first-order diversity includes all species with a weight precisely proportional to their abundance in the community (Hill 1973; Jost 2006; Moreno et al. 2011). In ethnographic sampling, all species reported by the inhabitants correspond to a site, and they have the same representation in the sample regardless of their frequency of mention, so this proportion is maintained. For this index, second-order diversity $\left({ }^{2} \mathrm{D}\right)$ is also calculated, but its application is not recommended for the present case, because this measure is based on the dominance of the species present in a sample (Jost 2006; Moreno et al. 2011; 2017). In ethnobiological data we have ethnospecies that are represented with a high frequency of mention, which may be biased towards some cultural or even economic preference that strongly influences its frequent mention, which we consider could cause bias.

We suggest that the suitability of biodiversity metrics should be evaluated for use in ethnobiological studies, in order to determine whether an ethnographic sample behaves in a similar way to an ecological sample. The relevance of other indexes should be considered as well; not only those that are based on incidence but also those that take abundance values into account. We consider that using ethnobiological or social-ecological units (taxonomic species + cultural assignment) and making comparisons between the degree of biological diversity and the diversity of ethnospecies are sufficient reason to apply more refined forms of analysis to evaluate biocultural diversity. However, it is essential to ensure the quality of the methodological design such that it involves proper collection of sufficient data, to avoid a subjective interpretation.

\section{Trends of use}

One of the most important characteristics of biocultural diversity is its use by human groups. Studies in other regions of Mexico have documented various use categories for different taxonomic groups (Lira et al. 2009; Monroy-Vilchis et al. 2008). In this study, 11 categories, which contribute to satisfying a wide range of human needs, were identified. Different indigenous groups use species in different ways for different purposes, which reflects the importance of nature in contemporary societies (Alonso-Castro et al. 2011; Carbajal-Esquivel et al. 2012; Toledo 1994).

In addition to the application of appropriate metrics, the use of multivariate statistical methods provides a broader view of the social-ecological relationships in the study area. In this case, implementing CA 
enabled a graphical association to be made between use categories and the various taxonomic groups. Several authors have used these methods, finding structural relationships between the study groups; e.g., between taxonomic families and habitat types (Molares and Ladio 2009), species management types (Parra et al. 2012), species (Zamudio and Hilgert 2012) and knowledge among several indigenous groups (Núñez-García et al. 2012). We found that certain biological groups are associated with specific categories, as a characteristic of the biological group and its use.

\section{CONCLUSIONS}

The Nahuas of the Huasteca region in the state of Hidalgo have extensive knowledge and make widespread use of the biodiversity in their territories. This study has shown that each of the vegetation types contributes particular characteristics in terms of socialecological relationships at the cultural level, a phenomenon associated with the presence of unique species of the tropical semievergreen forest and the montane cloud forest. However, since the two study communities belong to the same indigenous group, are located in the same geographical region and are in contact with the same widely distributed and introduced species, there are strong similarities in their knowledge and use of these species. In addition, it was found that each of the biological groups contributes in a particular way and in some cases exclusively in their respective use categories, especially in the case of plants and animals.

This study contributes to a comprehensive view of the multitaxonomic analysis of biodiversity known and used by a indigenous group, by combining the three main ethnobiological subdisciplines: ethnobotany, ethnomycology and ethnozoology (Figure 5). It is suggested that the conceptualization of biocultural diversity be extended beyond its cultural and biological components. We propose that biocultural diversity be considered as "the variety of organisms that are known, named, classified, organized, used, exploited, domesticated and/or manipulated by different human societies"; including the social-ecological systems of which this diversity forms a part at various spatiotemporal scales (Gutiérrez-Santillán 2019b).

It is composed essentially of ethnospecies, which consist of a taxonomic entity (species) together with its cultural counterpart (traditional name). When the basic units of biocultural diversity are defined, they can be analyzed using the new metrics used for the analysis of biological diversity, enabling a better assessment of biocultural diversity and more robust data to be generated, which can be compared on the intra- or interethnic level, between regions, ecosystems, or other divisions. In addition, this approach can be used to generate and provide sociocultural data for the implementation of conservation strategies under a biocultural approach.

\section{ACKNOWLEDGEMENTS}

Thanks are expressed to the residents of the study communities who kindly supported this research and contributed their invaluable knowledge, and to the UAEH for its support of AMF, ASG and GSR so that this research could be carried out. TVGS received a scholarship from CONACyT (389096/254575). 


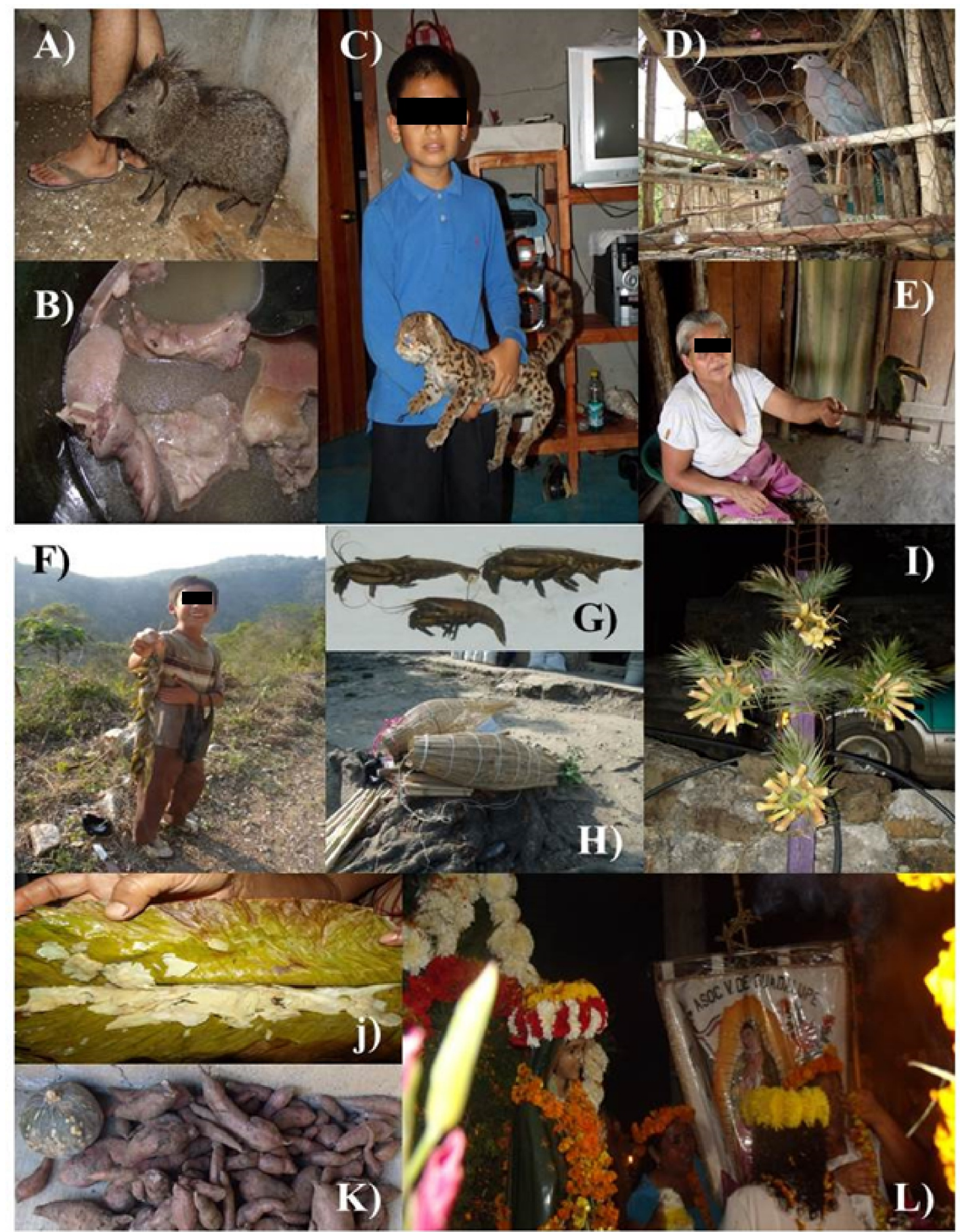

Figure 5. A) Pet boar (Tayassu tajacu, MCF); B) Striped (lowland) paca meat (Cuniculus paca, TSEF); C) Child with preserved margay (Leopardus weidii, MCF); D) Pet red-billed pigeon (Patagioenas flavirostris, TSEF); E) Informant with preserved emerald toucanet (Aulacorhynchus prasinus, MCF); F) Child fisherman (TSEF); G) crayfish (Procambarus sp., TSEF); H) cosol, river crayfish trap (TSEF); I) Cross decorated with cycad leaves (Zamia herrerae, MCF); J) Itztacnanacatl fungus on papatla leaf (Pleurotus albidus, Heliconia collinsiana; MCF); K) yam and squash (Ipomoea batatas, Cucurbita maxima; TSEF); L) two species of marigold (cempoal) in ceremony for festival of Our Lady of Guadalupe (Dec. 12) (Tagetes coronopifolia, Tagetes erecta; TSEF). TSEF = tropical semi-evergreen, MCF $=$ montane cloud forest. 


\section{REFERENCES}

Aguilar-López M, Rojas-Martínez A, CornejoLatorre C, Sánchez-Hernández C, Vite-Silva VD, Ramos-Frías J (2015) Registros notables de mamíferos terrestres del estado de Hidalgo, México. Acta Zoológica Mexicana (n.s.) 31(3): 403-411.

Albino-García C, Cervantes H, López M, RíosCasanova L, Lira R (2011) Patrones de diversidad y aspectos etnobotánicos de las plantas arvenses del valle de TehuacánCuicatlán: el caso de San Rafael, municipio de Cioxcatlán, Puebla. Revista Mexicana de Biodiversidad 82:1005-1019.

Albuquerque UP, Medeiros PM, Ferreira-Junior W, Silva TC, Silva RR, Goncalves-Souza T (2019) Social-ecological theory of maximization: basic concepts and two initial models. Biological Theory doi.org/10.1007/s13752-019-00316-8.

Albuquerque UP, Santos-Gonçalves $\mathrm{PH}$, Ferreira-Júnior W, Silva-Chaves L, Silva-Oliveira RC, Lima-Silva TL, DosSantos GC, Lima-Araíjo E (2018) Humans as niche constructors: Revisiting the concept of chronic anthropogenic disturbances in ecology. Perspectives in Ecology and Conservation 16(1): 1-11. doi.org/10.1016/j.pecon.2017.08.006.

Albuquerque UP, Ferreira-Júnior W (2017) What do we study in evolutionary ethnobiology? Defining the theoretical basis for a research program. Evolutionary Biology 44(2): 206-215 doi.org/10.1007/s11692-016-9398-z.

Albuquerque UP, Ferreira-Júnior W, Santoro FR, Torres-Avilez WM, Sousa-Júnior JR (2015). Niche construction theory and ethnobiology. In: Albuquerque UP, Medeiros PM, Casas A (eds). Evolutionary ethnobiology. Springer. New York, USA. pp. 73-87.

Albuquerque UP, Cunha L, Lucena R,Alves RRN (2014) Methods and techniques in ethnobiology and ethnoecology. 1ed. Springer, New York, USA doi:10.1007/978-1-4614-8636-7.

Alcántara-Salinas G, Ellen R, Valiñas-Coalla L, Caballero J, Argueta-Villamar A (2013) Alternative ways of representing zapotec and cuicatec folk classification of birds: a multidimensional model and its implications for culturally-informed conservation in Oaxaca, Mexico. Journal of Ethnobiology and Ethnomedicine 9:81 doi:10.1186/1746-4269-981.
Alcorn JB (1981a) Huastec noncrop resource management: implications for Prehistoric rain forest management. Human Ecology 9:395-417.

Alcorn JB (1981b) Some factors influencing botanical resource perception among the Huastec: suggestions for future ethnobotanical inquiry. Journal of Ethnobiology 1:221-230.

Alcorn JB (1983) El te'lom huasteco: presente, pasado y future de un sistema silvicultural indígena. Biótica 8:315-331.

Alcorn JB (1984) Huastec mayan ethnobotany. 1ed. University of Texas Press, Austin, U.S.A.

Aldasoro-Maya EM (2012) Documenting y contextualizing Pjiekakjoo (Tlahuica) knowledges though a collaborative research project. PhD Thesis, University of Washington, Washington D.C., U.S.A.

Alonso-Castro AJ, Carranza-Álvarez C, Maldonado-Mirya JJ, Jacobo-Salcedo MR, Quezada-Rivera DA, Lorenzo-Márquez $H$, Figueroa-Zúñiga LA, Fernández-Galicia $C$, RíosReyes NA, León-Rubio MA, Rodríguez-Gallegos V, Medellín-Milán P (2011) Zootherapeutic practices in Aquismón, San Luis Potosí, México. Journal of Ethnopharmacology 138(1):233-237 doi:10.1016/j.jep.2011.09.020.

Álvarez F, Villalobos JL, Armendariz G, Hernández C (2012) Relación biogeográfica entre cangrejos dulceacuícolas y acociles a lo largo de la zona mexicana de transición: revaluación de la hipótesis de Rodríguez (1986). Revista Mexicana de Biodiversidad 83: 1073-1083.

Álvarez MS (2002) Cambio sociocultural y usos de recursos forestales de las selvas, en una comunidad tepehua: El caso de Pisaflores en la Huasteca Veracruzana. Undergraduate thesis, Escuela Nacional de Antropología e Historia, México.

Alves MM, Faria S, Alves RRN (2016) Wild vertebrates kept as pets in the semiarid region of Brazil. Tropical Conservation Science 9:354-368.

Andrade-Cetto A (2009) Ethnobotanical study of the medicinal plants from Tlanchinol, Hidalgo, México. Journal of Ethnopharmacology 122:163-171 doi: 10.1016/j.jep.2008.12.008.

Argueta-Villamar A (2008) Los saberes p'urhépecha. Universidad Michoacana de San Nicolás de Hidalgo - Universidad Nacional 
Autónoma de México - Gobierno del Estado de Michoacán - Programa de Naciones Unidas para el Medio Ambiente, D.F., México.

Báez L, Garret G, Pérez D, Moreno B, Fierro UJ, Hernández MG (2012) Los pueblos indígenas de Hidalgo: Atlas etnográfico. Instituto Nacional de Antropología e Historia - Gobierno del Estado de Hidalgo - Consejo Estatal para la Cultura y las Artes de Hidalgo, D.F., México.

Barthas B (1996) De la selva al naranjal (transformaciones en la agricultura indígena en la Huasteca potosina. In: Bovin P (ed), El campo mexicano: una modernización a marchas forzadas. 1 ed. Centro Francés de Estudios Mexicanos y Centroamericanos (CEMCA) Institut Francais de Recherche Scientifique pour le Développement en Coopération (ORSTOM), D.F., pp. 183-199.

Bautista-Nava E (2007) Taxonomía y conocimiento tradicional de Cantharellus F. (Fungi, Cantharellaceae) en el noreste del estado de Hidalgo. Undergraduate thesis, Universidad Autónoma del Estado de Hidalgo, México.

Benz BE, Cevallos J, Santana F, Rosales J, Graf $S$ (2000) Losing knowledge about plant use in the sierra de Manantlan Biosphere Reserve, Mexico. Economic Botany 54:183-191.

Berlin B (1973) Folk systematics in relation to biological classification and nomenclature. Annu Rev Ecol Evol Syst 4:259-27.

Berlin B, Breedlove DE, Raven PH (1973) General principles of classification and nomenclature in folk biology. Am Anthropol 75:214-242.

Bernard HR (2006) Research methods in anthropology, qualitative and quantitative approaches. 4ed. Altamira Press, Lanham, New York, Toronto, Oxford.

Boege E. 2008. El patrimonio biocultural de pueblos indígenas de México. Comisión Nacional para el Conocimiento y Uso de la Biodiversidad, D.F., México.

Brewer D (1995) Cognitive indicators of knowledge in semantic domains. Journal of Quantitative Anthropology 5:107-28.

Brewer D (2002) Supplementary interviewing techniques to maximize output in free listing tasks. Field Methods 14:108-118.
Brook RK, McLachlan SM (2008) Trends and prospects for local knowledge in ecological and conservation research and monitoring. Biodiversity and Conservation 17:3501-3512.

Bueno J (2012) Diplópodos: los desconocidos formadores de suelo. Biodiversitas 102:1-5.

Bye R, Linares E (2000) Relationships between mexican ethnobotanical diversity and indigenous peoples. In: Minnis PE, Elisens WJ (eds) Biodiversity and Native America, University of Oklahoma, Oklahoma, USA, pp. 44-73.

Caballero N, Mapes C (1985) Gathering and subsistence patterns among the p'urhepecha indians of Mexico. Journal of Ethnobiology 5:31-47.

Cano O (1988) Herbolaría y Etnozoología en Papantla. Dirección General de Culturas Populares - SEP, México.

Carbajal-Esquivel $\mathrm{H}$, Fortanelli J, García-Pérez J, Reyes-Agüero JA, Yáñez-Espinosa L, Bonta M (2012). Use value of food plants in the Xi'iuy indigenous community of Las Guapas, Rayon, San Luis, Mexico. Ethnobiology Letters 3:39-55 doi.org/10.14237/ebl.3.2012.40.

Cardillo M, Bromham L, Greenhill SJ (2015) Links between language diversity and species richness can be confounden by spatial autocorrelation. Proc.R.Soc. B 282: 20142986 doi.org/10.1098/rspb.2014.2986

Ceballos G, Oliva G (2005) Los mamíferos silvestres de México. Comisión Nacional para el Conocimiento y Uso de la Biodiversidad Fondo de Cultura Económica, D.F., México.

Chao A, Lee, SM (1992) Estimating the number of classes via sample coverage. Journal of the American Statistical Association 87:210-217 dio.10.2307/2290471.

Correa-Sandoval A (2003) Gastrópodos terrestres del Noreste de México. Revista de Biología Tropical 51 (Suppl. 3:507-522.

Corwell RK, Mao CX, Chang J (2004) Interpolating, extrapolating, and comparing incidence based species accumulation curves. Ecology 85:2717-2727.

De Ávila A (2008) La diversidad lingüística y el conocimiento etnobiológico. In: Capital Natural de México, vol. I: Conocimiento actual de la biodiversidad. 1 ed. CONABIO, México, pp. 497556. 
Dunn CP (2008) Biocultural diversity should be a priority for conservation. Nature 456: 315.

Elands BHM, Vierikko K, Anderson E, Fischer Lk, Gonçalves P, Haase D, Kowarik I, Luz AC, Niemelä J, Santos-Reis M, Wiersum KF (2018) Biocultural diversity: A novel concepts to assess human-nature interrelations, nature conservation and stewarship in cities. Urban Forestry \& Urban Greening doi.org/10.1016/j.ufug.2018.04.006.

Escalante T (2003) ¿Cuántas especies hay? Los estimadores no paramétricos de Chao. Elementos, 52:53-56.

Farfán B, Casas A, Ibarra-Manríquez G, PérezNegrón E (2007) Mazahua ethnobotany and subsistence in the Monarch Butterfly Biosphere Reserve, Mexico. Economic Botany 61:173-191 doi.10.1663/00130001(2007)61[173:MEASIT]2.0.CO;2

Gallardo-Arias P (2004) Los especialistas de la curación: curanderos teenek y nahuas de Aquismón. Anales de Antropología 38:179-200.

Garibay-Orijel R, Caballero J, Estrada-Torres A, Cifuentes J (2007) Understanding cultural significance, the edible mushrooms case. Journal of Ethnobiology and Ethnomedicine doi:10.1186/1746-4269-3-4

Gavin MC, McCarter J, Mead A, Berkes F, Stepp JR, Peterson D, Tang R (2015) Defining biocultural approaches to conservation. Trends in Ecology \& Evolution 30:140-145 doi.org/10.1016/j.tree.2014.12.005.

González KA, Ramírez A, Sánchez E, Montaño, SE (2010) Los peces de la huasteca hidalguense. Universidad Autónoma del Estado de Hidalgo - Fondo Mixto CONACyT - Gobierno del Estado de Hidalgo, México.

Gorenflo LJ, Romaine S, Mittermeier R, WalkerPainemilla K (2012) Co-occurrence of linguistic and biological diversity in biodiversity hotspots and high biodiversity wilderness areas. Proceedings of the National Academy of Sciences of the United States of America 109:8032-8037 doi.10.1073/pnas.1117511109.

Grasser S, Schunko C, Vogl CR (2012) Gathering "tea" from necessity to connectedness with nature. Local knowledge about wild plant gathering in the Biosphere Reserve Grosses Walserta (Austria). Journal Ethnobiology and Ethnomedicine 8:31.
Gutiérrez-Santillán TV, Albuquerque UP, Valenzuela-Galván D, Reyes-Zepeda F, Vázquez L-B, Mora-Olivo A, Arellano-Méndez LU (2019a) Trends on mexican ethnozoological research, vertebrates case: a systematic review. Ethnobiology and Conservation 8:1 doi:10.15451/ec2019-01-8.01-1-39.

Gutiérrez-Santillán TV, Valenzuela-Galván D, Albuquerque UP, Reyes-Zepeda F, Arellano-Uriel LU, Mora-Olivo A, Vásquez L-B (2019b). The spatiotemporal scale of ethnobiology: A conceptual contribution in the application of meta-analysis and the development of the macro-ethnobiological approach. In Alguquerque UP, Paiva RF, Fernandes LV, Alves RR. Methods and Techniques in Ethnobiology and Ethnoecology. New York, USA doi.org/10.1007/978-1-4939-8919-5.

Gutiérrez-Santillán TV (2018) Meta-análisis y macro-etnobiología: nuevas perspectivas de investigación etnobiológica, el caso de la etnozoología mexicana. PhD Thesis, Universidad Autónoma de Tamaulipas, México.

Gutiérrez-Santillán TV (2013) Diversidad biocultural y especies bioculturales clave: un estudio etnobiológico en dos comunidades nahuas en la Huasteca Hidalguense. MSc. dissertation, Universidad Autónoma del Estado de Hidalgo, México.

Hammer $\varnothing$, Harper DAT, Ryan PD (2001) PAST: Paleontological statistics software package for education and data analysis. Palaeontologia Electronica 4:1-9.

Harmon D, Loh J (2010) The index of linguistic diversity: A new quantitative measure of trends in the status of the world's languages. LD\&C 4:97-151.

Hernández L, Bautista B (2011) Diccionario de nombres científicos náhuatl, comunes en español y comunes en inglés de cinco grupos de vertebrados de la Huasteca hidalguense. Undergraduate Thesis, Instituto Tecnológico de Huejutla, México.

Hernández V (2003) Estudio etnobotánico medicinal de dos comunidades del municipio de Atlapexco en el estado de Hidalgo. Tlatemolistli tle xiuipajtli ipan ome chinantli tlen Atlapech chinankotlatilanketl ipan Hidalgo Tlatokajyotl. Undergraduate thesis, Universidad Nacional Autónoma de México, México. 
Hill MO (1973) Diversity and evenness: a unifying notation and its consequences. Ecology 54:427-432.

Hong SK (2013) Biocultural diversity conservation for island and islanders: Necessity, goal and activity. Journal of Marine and Island Cultures. 2: 102-106 doi.org/10.1016/j.imic.2013.11.004.

Hopkins AL, Stepp JR (2012) Distribution of Herbal Remedy Knowledge in Tabi, Yucatan, Mexico. Economic Botany 66:249-254.

Howell SNG, Webb S (1995) A guide to the birds of Mexico and Northern Central America. 1 ed. Oxford University Press, New York, U.S.A.

Hunn E (1998) Mixtepec Zapotec ethnobiological classification: A preliminary sketch and theoretical commentary. Anthropologica 40: 35-48.

Hunn E (2008) A Zapotec natural history: trees, herbs, and flowers, birds, beasts, and bugs in the life of San Juan Gbëë. 1ed. University of Arizona Press, Tucson, U.S.A.

Hunn E (2011) Ethnozoology. In: Anderson EN, Pearsall DM, Hunn E, Turner NJ (eds) Ethnobiology. Wiley-BlackwellI, U.S.A. pp. 83-96.

Huntington HP (2013) Local knowledge as a resource for Nepal: building partnerships with scientists and conservationists Conservation Science 1:1-4 doi.org/10.3126/cs.v1i1.8577.

INALI Instituto Nacional de Lengua Indígena (2008). Catálogo de las lenguas indígenas nacionales: variantes lingüísticas de México con sus autodenominaciones y referencias geoestadísticas. Diario Oficial de la Federación. Gobierno de México, D.F., México.

INEGI. 2010. Anuario estadístico del estado de Hidalgo. Aguascalientes, Aguascalientes, México.

International Society of Ethnobiology, 2006, http://ethnobiology.net/code-of-ethics/

Isidoro-Resendiz D (2011) Importancia cultural de los hongos comestibles en el municipio de Tepehuacán de Guerrero, Hidalgo. Undergraduate thesis, Universidad Autónoma del Estado de Hidalgo, México.
Jaimes MI, Gómez G, Pacheco N, Reyes SR (2014) Uso y manejo de la avifauna en San Miguel Tzinacapan, municipio de Cuetzalan del Progreso, Puebla, México. In: VásquezDávila MA (ed.) Aves, personas y culturas: estudios de etno-ornitología 1. Red de Etnoecología y Patrimonio Biocultural CONACyT - Instituto Tecnológico del Valle de Oaxaca - Cartel Editores - Universidad Tecnológica del Chocó. Oaxaca, México, pp 243259.

Jiménez-Valverde A (2003) Las curvas de acumulación de especies y la necesidad de evaluar la calidad de los inventarios biológicos. Revista lbérica de Aracnología 8:151-161

Jost L (2006) Entropy and diversity. Oikos 113:363-375 doi.org/10.1111/j.2006.00301299.14714.x.

Krell FT (2004) Parataxonomy in biodiversity studies-pitfalls and applicability of 'morphospecies' sorting. Biodiversity and Conservation 13(4): 795-812.

Lira R, Casas A, Rosas-López R, Paredes-Flores $M$, Pérez-Negrón $E$, Rangel-Landa $S$, Solís $L$, Torres I, Dávila, P. (2009). Traditional knowledge and useful plant richness in the Tehuacán-Cuicatlán Valley, Mexico. Economic Botany 63:271-287 doi.org/10.1007/s12231-0099075-6.

Loh J, Harmon D (2005) A global index of biocultural diversity. Ecological Indicators 5:321-241

doi.org/10.1016/j.ecolind.2005.02.005.

López del Toro, P., Andresen E, Barraza L, Estrada A (2009) Attitudes and knowledge of shade-coffee farmers towards vertebrates and their ecological functions. Tropical Conservation Science 2: 299-318.

López-Villafranco ME, Aguilar-Contreras A (2010) Etnobotánica médica de los tepehuas de Hidalgo. In: Moreno A, Pulido MT, Mariaca R, Valadez R, Mejía P, Gutiérrez TV (eds) Sistemas biocognitivos tradicionales: paradigmas en la conservación biológica y el fortalecimiento cultural. Asociación Etnobiológica Mexicana A.C. - Global Diversity Foundation - Universidad Autónoma del Estado de Hidalgo - El Colegio de la Frontera Sur - Sociedad Latinoamericana de Etnobiología. D.F. México, pp 284-291. 
Lozada M, Ladio A, Weigandt M (2006) Cultural transmission of ethnobotanical knowledge in a rural community of northwestern Patagonia, Argentina. Economic Botany 60:374-385 doi.org/10.1663/00130001(2006)60[374:CTOEKI]2.0.CO;2.

Luna I, Ocegueda S, Alcántara O (1994) Florística y notas biogeográficas del bosque mesófilo de montaña del municipio de Tlanchinol, Hidalgo, México. Anales del Instituto de Biología, Serie Botánica 65:31-62.

Luque D, Doode S (2010) Los comcáac (seri): hacia una diversidad biocultural del Golfo de California y estado de Sonora. Estudios Sociales 1 (Esp.):274-300.

Maclaurin J., Sterelny K (2008) What is biodiversity?. The University of Chicago Press. Chicago, USA.

Maffi L, Dilts O (2014). Biocultural diversity toolkit: biocultural approaches to ceonservation \& development. Terrilingua, Salt Spring Island, British Columbia, Canada.

Maffi L, Woodley E (2008) Biocultural diversity conservation: a global sourcebook. (1ed) Earthscan. Columbia.

Maffi L (2007) Biocultural diversity and sustainability. In: Pretty $\mathrm{J}$, Ball $\mathrm{A}$, Benton $\mathrm{T}$, Guivant J, Lee D, Orr D, Pfeffer M, Ward H (eds) Sage handbook on environment and society. Sage Publications, London, pp 267-277.

Maffi L (2005) Linguistic, cultural and biological diversity. Terralingua, Salt Spring Island, British Columbia, Canada.

Maffi $L$ (2001) On biocultural diversity linking language, knowledge, and the environment. Smithsonian Institution Press, Washington, U.S.A.

Martínez-Morales M (2007) Avifauna del bosque mesófilo de montaña del noreste de Hidalgo, México. Revista Mexicana de Biodiversidad 78:149-162.

Martínez-Morales $M$, Ortiz-Pulido $R$, de la Barreda B, Zuria IL, Bravo-Cadena J, ValenciaHerverth J (2007) Hidalgo. In: Ortiz-Pulido R, Navarro-Sigüenza A, Gómez de Silva $H$, RojasSoto O, Peterson TA (Eds.). Avifaunas Estatales de México. CIPAMEX, México, pp 49- 95.

Mejenes-López SMA, Hernández-Bautista $M$, Barragán-Torres J, Pacheco J (2010) Los mamíferos del estado de Hidalgo, México. Therya 1:161-188.
Mejenes-López SMA (2008) Mastofauna de la región Huasteca y Sierra de Hidalgo. Undergraduate thesis, Universidad Nacional Autónoma de México, México.

Miller RR (2009) Peces dulceacuícolas de México. CONABIO - Sociedad Ictiológica Mexicana A.C. - El Colegio de la Frontera Sur Consejo de los Peces del Desierto MéxicoEstados Unidos. D.F., México.

Molares S, Ladio A (2009) The usefulness of edible and medicinal Fabaceae in Argentina and Chilean Patagonia: Environmental availability and other sources of supply. Evidence-Based Complementary and Alternative Medicine 1:12 doi:10.1155/2012/901918.

Monroy-Vilchis $\mathrm{O}$, Cabrera L, Suárez $\mathrm{P}$, ZarcoGonzález MM, Rodríguez-Soto C, Urios V (2008) Uso tradicional de vertebrados silvestres en la Sierra Nanchititla, México. Interciencia 33:308-313.

Montaño SE, Moreno A, González KA (2010) Revalorando la pesca náhuatl como ejemplo de una práctica sustentable: estudio de caso en la región hidalguense, México Central. In: Moreno A, Pulido MT, Mariaca R, Valadez R, Mejía P, Gutiérrez TV (eds) Sistemas biocognitivos tradicionales: paradigmas en la conservación biológica y el fortalecimiento cultural. Asociación Etnobiológica Mexicana A.C. - Global Diversity Foundation - Universidad Autónoma del Estado de Hidalgo - El Colegio de la Frontera Sur - Sociedad Latinoamericana de Etnobiología. D.F., México, pp 317-321.

Montoya JJ (1968) Magia y cacería entre los nahuas de la Sierra de Hidalgo. Boletín INAH 34:22-23.

Morales-García AD, Acosta-Rosales A (2015) Registros recientes de jaguar (Panthera onca) en el estado de Hidalgo, México. Revista Mexicana de Mastozoología Nueva Época 5(2): 66-72.

Moreno CE, Calderón-Patrón JM, ArroyoRodríguez V, Barragán F, Escobar F, GómezOrtiz Y, Martín-Regalado N, Martínez-Falcón AP, Martínez-Morales MA, Mendoza E, OrtegaMartínez IJ, Pérez-Hernández CX, Pineda E, Pineda-López R, Rios-Díaz CL, Rodríguez P, Rosas F, Schondube JE, Zuria I (2017) Measuring biodiversity in the Anthropocene: a simple guide to helpful methods. Biodiversity and Conservation 20(12): 2993-2998 doi.10.1007/s10531-017-1401-1. 
Moreno CE, Barragán F, Pineda E, Pavón NP (2011) Reanalizando la diversidad alfa: alternativas para interpretar y comparar información sobre comunidades ecológicas. Revista Mexicana de Biodiversidad 82:12491261.

Nabhan GP, Rea AM, Reichhardt KL, Mellink E, Hutchinson CF (1982) Papago influence on habitat and biotic diversity: Quitovac oasis ethnoecology. Journal Ethnobiology 2: 124-143.

Neyra-González, L. Durand-Smith L. (1998) Biodiversidad. In: La diversidad biológica de México: Estudio de país. Comisión para el Conocimiento y uso de la Biodiversidad, México, pp. 61-102.

Núñez-García RM, Fuente-Carrasco ME, Venegas-Barrera CS (2012) La avifauna en la memoria biocultural de la juventud indígena en la Sierra Juárez de Oaxaca, México. Universidad y Ciencia 28(3): 201-216.

Olivier G (2008) Viaje a la Huasteca con Guy Stresser-Péan. Fondo de Cultura Económica CEMCA, D.F., México.

Parra F, Blancas JJ, Casas A (2012) Landscape management and domestication of Stenocerus pruinosus (Cactaceae) in the Tehuacán Valley: human guided selection and gene flow. Journal Ethnobiology and Ethnomedicine 8:1-32 doi. 10.1186/1746-4269-832.

Penguilly MA, Moreno A, Goyenechea I, Espinosa G (2010) Percepción acerca de las lagartijas consideradas nocivas por algunos otomíes, nahuas, tepehuas y mestizos en el estado de Hidalgo, México. In: Moreno $A$, Pulido MT, Mariaca R, Valadez R, Mejía P, Gutiérrez TV (eds) Sistemas biocognitivos tradicionales: paradigmas en la conservación biológica y el fortalecimiento cultural. Asociación Etnobiológica Mexicana A.C. - Global Diversity Foundation - Universidad Autónoma del Estado de Hidalgo - El Colegio de la Frontera Sur Sociedad Latinoamericana de Etnobiología, D.F., México, pp 99-105.

Pennington TD, Sarukhán J (2005) Árboles tropicales de México, manual para la identificación de las principales especies. Universidad Nacional Autónoma de México Fondo de Cultura Económica, D.F., México.
Pérez-Escandón BE, Villavicencio-Nieto MA, Ramírez-Aguirre A (2003) Lista de plantas útiles del estado de Hidalgo. Universidad Autónoma del Estado de Hidalgo, México.

Peterson RT, Chalif EL (2000) Aves de México. Guía de Campo. Editorial Diana, D.F., México.

Pineda R, Verdú JR (2013) Cuaderno de prácticas. Medición de la biodiversidad: diversidades alfa, beta y gamma. Universidad Autónoma de Querétaro - Universidad de Alicante, México.

Piotrowska Z (2013a) No sé si los aires ven con coraje que voy a hacer curaciones. Misión del curandero, sus desafíos y peligros según los nahuas de la Huasteca hidalguense. In: La terca realidad. La Huasteca como espejo cultural. CIESAS - El Colegio de San Luis S.C., México.

Piotrowska Z (2013b) Cerros y curanderos entre los nahuas de la Huasteca. In: La terca realidad. La Huasteca como espejo cultural. CIESAS - El Colegio de San Luis S.C., México.

Pretty J, Adams B, Berkes F, Ferreira S, Dudley $N$, Hunn $E$ (2009). The intersections of biological diversity and cultural diversity: Towards integration. Conservation and Society 7(2): 100-112 doi:10.4103/0972-4923.58642.

Puig H (1991) Vegetación de la Huasteca (México) Estudio fitogeográfico y ecológico. Institut Francais de Recherche Scientifique pour le Développement en Coopération (ORSTOM) Instituto de Ecología A.C. - Centre D’Estudes Mexicaines et Centraméricaines (CEMCA), D.F., México.

Ramírez-Bautista A, Sánchez-González A, Sánchez-Rojas G, Cuevas-Cardona C. (2017) Biodiversidad del Estado de Hidalgo. 1ed Universidad Autónoma del Estado de Hidalgo, Consejo Nacional de Ciencia y Tecnología, México.

Ramírez-Bautista A, Hernández-Salinas U, CruzElizalde R, Berriozabal-Islas C, Lara-Tufiño D, Goyenechea I, Castillo-Cerón JM (2014) Los anfibios y reptiles de Hidalgo, México: Diversidad, biogeografía y conservación. Sociedad Herpetológica Mexicana, México.

Ruvalcaba J, Pérez JM, Herrera O (2004) La Huasteca, un recorrido por su diversidad. CIESAS - EI Colegio de San Luis - El Colegio de Tamaulipas, México. 
Saslis-Lagoudakis CH, Clarke AC (2013) Ethnobiology: the missing link in ecology and evolution. Trends in Ecology \& Evolution 28:67-68 doi: 10.1016/j.tree.2012.10.017.

StatSoft Inc (2004) STATISTICA (Data Analysis Software System) versión 7. www.statoft.com

Stepp JR, Castaneda H, Cervone S (2005) Mountains and biocultural diversity. Mountain Research and Development 25(3): 223-227 doi.org/10.1659/0276-

4741(2005)025[0223:MABD]2.0.CO;2.

Stepp JR, Cervone S, Castaneda H, Lasseter A, Stocks G, Gichon Y (2004) Development of a GIS for global biocultural diversity. Policy Matters 13: 267-271.

Sutherland WJ (2003) Parallel extinction risk and global distribution of languages and species. Nature 423: 276-279.

Toledo VM (2010) La biodiversidad de México. Inventarios, manejos, usos, informática, conservación e importancia cultural. FCE, CONACULTA. D.F., México.

Toledo VM (1994) Biodiversity and Cultural Diversity in Mexico. Different Drummer 1:16-19.

Toledo VM, Caballero J, Mapes C, Barrera N, Argueta A, Nuñez MA (1983) Los purépechas de Patzcuaro: Una aproximación ecológica. 2ed Serie Etnociencia: Cuadernos de Etnobiología 1 - Secretaría de Educación Pública - Dirección General de Culturas Populares, D.F., México.

Torres JC, Fortanelli J, van't Hooft A, Benítez V (2015) Etnobotánica de la vivienda rural en la región Xi'iuy de la Palma, San Luis Potosí, México. Etnobiología 13:21-36.
Trotter RT, Needle RH, Goosby E, Bates C, Singer M (2001) A Methodological Model for Rapid Assessment, Response, and Evaluation: The RARE Program in Public Health. Field Methods 13:137-159.

Turner N, Deur D, Rae-Mellot C (2011) "Up on the mointain": Ethnobotanical importance of montane sites in pacific coastal North America. Journal of Ethnobiology 31(1): 4-43.

Turvey ST, Pettorelli N (2014) Spatial congruence in language and species richness but not threat in the world's top linguistic hotspot. Proceedings of the Royal Society B 281: 20141644 doi.org/10.1098/rspb.2014.1644.

Villaseñor JL (2016) Checklist of the native vascular plants of Mexico. Revista Mexicana de Biodiversidad 87:559-902.

Villavicencio MA (2005) Vegetación e inventario de la flora útil de la Huasteca y la zona OtomíTepehua de Hidalgo. SIZA-CONACYT Universidad Autónoma del Estado de Hidalgo, México.

Wolverton S, Chambers KJ, Veteto JV (2014) Climate Change and Ethnobiology. Journal of Ethnobiology 34:273-275.

Zamudio F, Hilgert N (2012) Descriptive attributes used in the characterization of stingless bees (Apidae: Meliponini) in rural populations of the Atlantic Forest (Misiones, Argentina). Journal Ethnobiology and Ethnomedicine 8:1-9 doi.org/10.1186/1746-42698-9.

Received: 01 February 2019

Accepted: 28 May 2019

Published: 21 June 2019 


\section{Supplementary Material}

List of biocultural diversity for two communities of the Huasteca, Hidalguense; the type of vegetation is tropical semi-evergreen forest (TSEF) and montane cloud forest (MCF). The table contains the following data: family, gender and species, local name in spanish and nahuatl, vegetation type (TSEF / MCF) and category of use and utilization (ceremonial= I, fuel= II, edible= III, IV= construction, $\mathrm{V}=$ timber, $\mathrm{VI}=$ pet, $\mathrm{VII}=$ medicinal, $\mathrm{VIII}=$ ornamental, IX= others, $\mathrm{X}=$ agricultural use, $\mathrm{XI}=$ trade).

\begin{tabular}{|c|c|c|c|c|}
\hline Family & Specie & $\begin{array}{c}\text { Traditional name } \\
\text { spani/náhuatl }\end{array}$ & $\begin{array}{c}\text { Type of } \\
\text { vegetation }\end{array}$ & $\begin{array}{l}\text { Category of use } \\
\text { and utilization }\end{array}$ \\
\hline \multicolumn{5}{|l|}{ MOLLUSCA } \\
\hline *Gasiropoda & ? & caracoles & TSEF/MCF & VII \\
\hline \multicolumn{5}{|l|}{ CRUSTACEA } \\
\hline${ }^{*}$ Caınbandae & Procambarus sp. & burrins / techichis & TSEF/MCF & III, XI \\
\hline \multirow[t]{2}{*}{ *Palaeınonidae } & Macrobranchium sp. & acaınayas & TSEF/MCF & III, XI \\
\hline & ? & cosoles & TSEF/MCF & III, XI \\
\hline \multicolumn{5}{|l|}{ DIPLOPODA } \\
\hline & ? & inipies & MCF & VII \\
\hline \multicolumn{5}{|l|}{ PISCES } \\
\hline Angulidae & Anguilla rostrata Lesueur, 1821 & coatimichi & TSEF & I, III, VII, VIII, „̌l \\
\hline Lepisosieıdae & Lepisosteus osseus IInnaeus, 1758 & peż aguja / huitzilmichi & TSEF & $I I I, V I I, x)$ \\
\hline Calosionide & Ictiobus labiosus \{'Meek, 1904) & tirompa de puerco / pitzolmichi & TSEF & III, х \\
\hline \multirow[t]{5}{*}{ Characidae } & Astyanax mexicanus De Fllippl, 1853 & poxia & MCF & III, $x \mid$ \\
\hline & Cichlasoma labridens \{Pellegrin, 亿003; & $\begin{array}{l}\text { inojarras / tecoxitle, xomaquictle, } \\
\text { xumaquictle }\end{array}$ & TSEF & $\|I I, V\|, x$ \\
\hline & Ciclastoma steindachneri (Jordan \& Snyder 1899) & $\begin{array}{l}\text { Ingjarras / tecoxitle, xomaquictle, } \\
\text { xumaquictle }\end{array}$ & MCF & III, 爻I \\
\hline & Herichthys cyanoguttatus Balrd y Girard, 1854 & $\begin{array}{l}\text { Ingjarias / tecoxitle, xomaquictle, } \\
\text { xumaquictle }\end{array}$ & MCF & $I I I, x \mid$ \\
\hline & Herichthys tamasopoensis (Artigas Ažas, $\{993$ ) & $\begin{array}{l}\text { Inojarras / tecoxitle, xomaquictle, } \\
\text { xumaquictle }\end{array}$ & TSEF/MCF & $\|I I, V\|, X I$ \\
\hline \multirow[t]{3}{*}{ Cichlidae } & Amatatlania nigrofasciata ;Gロnithel; $180 \bar{T}$; & $\begin{array}{l}\text { Ingjarlas / tecoxitle, xomaquictle, } \\
\text { xumaquictle }\end{array}$ & TSEF/MCF & $\|I I, V\|, x I$ \\
\hline & Oreochromis aureus 'Sitendachner 1८64) & illapla / xumaquictli & TSEF/MCF & III, $x$ \\
\hline & Oreochromis niloticus \{'-Innaeus, 1758; & îlapla / xumaquictli & TSEF/MCF & III, Х \\
\hline \multirow[t]{6}{*}{ Cyprinı dae } & Cyprinella lutrensis S. F. Barrd \& Girard, 1853 & sardina & TSEF & III, X \\
\hline & Cyprinus carpio communis (IIInnaeus, 1758; & calpa / olomichi & TSEF/MCF & III, $x \mid$ \\
\hline & Diona erimyzonops Hlubbs \& Muller 1974 & charal / poxta & MCF & III, XI \\
\hline & Diona ipni (Alvareč \& Navarro 1953) & charal / poxta & TSEF/MCF & $\|I I, V\|$, メl \\
\hline & Diona rasconis (Jordan \& Snyder 1900); & charal / poxta & TSEF & $\|I I, V\|, X I$ \\
\hline & Notropis tropicus ('Hubbs \& Miller, 1975) & charal / poxta & MCF & III, $x \mid$ \\
\hline Eleniridae & Gobiomorus dormitor Lacep $\square$ de, 1800 & huavıาa, guavina / tocoxite, tocoxitli & TSEF/MCF & III, Х \\
\hline \multirow[t]{3}{*}{ Ictalundae } & Ictalurus mexicanus '(Meek, 1904\}) & bagre / xolotl, miquecuani, xolomichi & TSEF/MCF & $I I I, V \|$, メl \\
\hline & 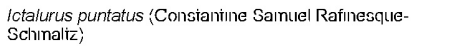 & bagre / xolott, miquecuani, xolomichi & TSEF/MCF & III, $x \mid$ \\
\hline & Pylodictis olivaris \{Rańlnesque, 18१८) & bagre / xolot, miquecuani, xolomichi & TSEF/MCF & $\| I I, V I I, x I$ \\
\hline Mugilidae & Agonostomus monticola_Bancrofi, 1834; & îrucha / itztacmichi & TSEF/MCF & $\| I I, V I I, x I$ \\
\hline \multirow[t]{9}{*}{ Poecilludae } & Gambusia vittata Hubus, 1926 & charal / poxta & TSEF/MCF & III, $x \mid$ \\
\hline & Heterandrai bimaculata ('Heckel, 1848; & charal / poxta & MCF & III, $x \mid$ \\
\hline & Poecilia latipunctata_Meek, 1904 & charal / poxta & $\mathrm{MCF}$ & III, ХI \\
\hline & Poecilia mexicana Sielndachnner, 1803 & charal / poxta & MCF & III, XI \\
\hline & Poeciliopsis gracilis__(Heckel, 1848) & chalal / poxta & MCF & III, $x \mid$ \\
\hline & Xiphophorus birchmanii & charal / poxta & MCF & $I I I, x I$ \\
\hline & $\begin{array}{l}\text { Xiphophorus continens Rauchenberger, Kallınan \& } \\
\text { Morizoi, } 1990\end{array}$ & charal / poxta & TSEF/MCF & $|I I, x|$ \\
\hline & $\begin{array}{l}\text { Xiphophorus malinche Rauchenberger, Kallınan \& Mor'zoi, } \\
\text { 1990 }\end{array}$ & chalal / poxta & TSEF/MCF & $|I I, x|$ \\
\hline & Xiphophorus variatus \{Meek, 1904$\}$ & charal / poxta & MCF & III, XI \\
\hline \multicolumn{5}{|l|}{ AMPHIBIA } \\
\hline \multirow[t]{3}{*}{ Buíonadae } & Incilius nebulifer 'GIrard, 1843\} & ranas, ranías y sapos & TSEF/MCF & VII \\
\hline & Incilius occidentalis 'Cannerano, 1879 ; & ranas, raniras y sapos & TSEF/MCF & VII \\
\hline & Rhinella marina !-nาาอeus, 1758 & ranas, rantias y sapos & TSEF/MCF & VII \\
\hline Cautdaía & $?$ & axolotl, xolotl & TSEF/MCF & \\
\hline \multicolumn{5}{|l|}{ REPTILIA } \\
\hline Kunosierndae & Kinosternon herrerai Stejneger, 1925 & irituga / coxuali & TSEF/MCF & $\mathrm{III}, \mathrm{VI}, \mathrm{VII}, \mathrm{VIII}$, ^l \\
\hline Anguidae & Gerrhonotus ophiurus Cope, 1866 & escorpi $\square$ / axilis & TSEF/MCF & \\
\hline Colyiophanidae & Corytophanes hernandesii Wieginalnn, 1828 & lagarìja verde / Iguana & TSEF & $\mathrm{VI}, \mathrm{xl}$ \\
\hline Gekkonidae & Hemidactylus frenatus Schlegel, 1836 & lagarìja g $\square$ era, huja / axilispitzilzilzitl & TSEF & \\
\hline Iguanıdae & Ctenosaura acanthura (Shaly, 1802) & lagarìja negra & TSEF & $V I_{1} \times l_{1}$ \\
\hline Boldae & Boa constrictor ('I-Innaeus, 1758; & venadillo / mazaticoatl & TSEF/MCF & $\| I I, V I I I, x I$ \\
\hline Colubridae & Coniophanes imperialis 'Balr y Girard, 1859 ; & v $\square$ bora de agua & TSEF & \\
\hline
\end{tabular}




\begin{tabular}{|c|c|c|c|c|}
\hline & Drymarchon melanurus (Dun $\square$ ril, Bibron y Dun $\square$ rll, 1854; & v $\square$ bora negra / tepeticoatl & TSEF/MCF & VIII, $X I$ \\
\hline & Drymobius margaritiferus (Schlegel, 183T) & chirrinnera / chacuatla & TSEF/MCF & \\
\hline & Lampropeltis triangulum \{Lac $\square$ pede, $17 \circ 8$; & corralllo / zicatena & TSEF/MCF & 资 \\
\hline & $\begin{array}{l}\text { Spilotes pullatus (LInnaeus, 1758) } \\
\text { Tantilla rubra 'Cope, 1870\%) }\end{array}$ & $\begin{array}{l}\text { apachire / apaxcoatl } \\
\text { corallillo / zicatena }\end{array}$ & TSEF/MCF & $V / I I, V I I I$, ג \\
\hline Dipsadidae & Tropidodipsas sartorii Cope, 18063 & corallillo / zicatena & TSEF/MCF & Ix \\
\hline Elapidae & 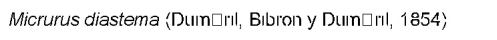 & corralllo / zicatena & TSEF/MCF & x \\
\hline Nailicidae & Nerodia rhombifer \{'Hallowell, 1852; & vघbora de agua & TSEF & \\
\hline \multirow[t]{2}{*}{ Viperidae } & Agkistrodon taylori Burger y Robeison, 1951 & cola blanca / xochicuitlapiliti & TSEF/MCF & I, X \\
\hline & $\begin{array}{l}\text { Atropoides nummifer \{Rロppell, } 1845 \text {; } \\
\text { Bothrops asper 'Gerinan, } 1884 \text {; } \\
\text { Crotalus sp. LInnaeus, } 1758\end{array}$ & $\begin{array}{l}\text { meilapıl / metlapilli } \\
\text { mahuaquite } \\
\text { vロuora de cascabel }\end{array}$ & $\begin{array}{l}\text { TSEF/MCF } \\
\text { TSEF/MCF } \\
\text { TSEF/MCF }\end{array}$ & $\begin{array}{l}I, I x \\
I, V I I, I X, x I \\
I, V I I, I x, x I\end{array}$ \\
\hline \multicolumn{5}{|l|}{ AVES } \\
\hline Tinainidae & Crypturellus cinnamomeus \{L-esson, 1842\} & perdiz / xacoyot/ & TSEF/MCF & $I I I, V I, V I I . V I I I, x \mid$ \\
\hline \multirow[t]{2}{*}{ Cracidae } & $\begin{array}{l}\text { Cairina moschata '\{!nnaeus, 1758; } \\
\text { Ortalis vetula \{'Wagler, } 1830\} \\
\text { Penelope purpurascens Wagler, } 1830\end{array}$ & $\begin{array}{l}\text { pain negro / patox } \\
\text { chachalaca / ecuetlacte } \\
\text { cojollie / cojolictli }\end{array}$ & $\begin{array}{l}\text { TSEF/MCF } \\
\text { TSEF/MCF } \\
\text { TSEF/MCF }\end{array}$ & 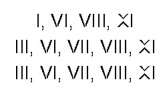 \\
\hline & Crax rubra LInnaeus, 1758 & 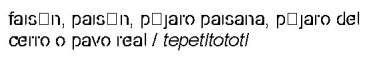 & TSEF & $\mathrm{I},\|I I, \mathrm{~V} \mid \mathrm{V}\| \mathrm{II}, \mathrm{VII}, \mathrm{xI}$ \\
\hline \multirow[t]{2}{*}{ Odoniophorrdae } & $\begin{array}{l}\text { Dendrortyx barbatus Gould, } 1846 \\
\text { Colinus virginianus \{LInnneus, 1758; }\end{array}$ & 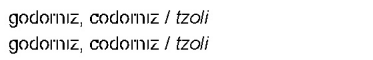 & $\begin{array}{l}\text { TSEF/MCF } \\
\text { IMCF }\end{array}$ & 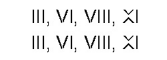 \\
\hline & Dactylortyx thoracicus (Gainbel, 1848; & godorinz, codomiz / tzoli & MCF & $\| I I, V I, V I I I, x l$ \\
\hline Ciconıdae & Mycteria americana LInnaeus, 1758 & CIg $\square$ $\square a$ & TSEF & \\
\hline Pelecanidae & Pelecanus erythrorhynchos Ginelin, $17 \circ 9$ & pel $\square$ cano & TSEF & \\
\hline \multirow[t]{2}{*}{ Ardeidae } & $\begin{array}{l}\text { Ardea alba \{LInnaeus, } 1758) \\
\text { Egretta caerulea \{'ㄴnnaeus, } 1758 \text {; }\end{array}$ & $\begin{array}{l}\text { garža, gaiza blanca } \\
\text { galża negra }\end{array}$ & $\begin{array}{l}\text { TSEF/MCF } \\
\text { TSEF }\end{array}$ & \\
\hline & Cochlearius cochlearius \{(Innาaeus, 17ôo' & cuchariva & TSEF & \\
\hline Caitharitidae & $\begin{array}{l}\text { Coragyps atratus (Bechsiem, } 1793 \text { ) } \\
\text { Cathartes aura ('IInnaeus, } 1758 \text {; }\end{array}$ & $\begin{array}{l}\text { zopiloie / zapilotl } \\
\text { zopiloie |ojo / zapilotl }\end{array}$ & $\begin{array}{l}\text { TSEF/MCF } \\
\text { TSEF }\end{array}$ & $\begin{array}{l}I, V \| I \\
I, V \| I\end{array}$ \\
\hline Accipirirdae & $\begin{array}{l}\text { Rupornis magnirostris \{Ginelin, 1788; } \\
\text { Buteo plagiatus 'SCchlegel, 1802) } \\
\text { Buteo jamaicensis 'Ginelin, 1788; }\end{array}$ & $\begin{array}{l}\text { pollero } \\
\text { पgulla, gavil } \square \text { / / cuatoctle } \\
\text { पgulla gavil } \square \text { / cuatoctle }\end{array}$ & $\begin{array}{l}\text { TSEF/MCF } \\
\text { TSEF } \\
\text { TSEF/MCF }\end{array}$ & 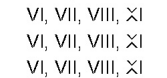 \\
\hline \multirow[t]{4}{*}{ Colunbidae } & Patagioenas flavirostris (Wagler, 1831\} & ìurcaz̄a, iøicaz̄a & TSEF/MCF & $\mathrm{III}, \mathrm{VI}, \mathrm{VII}, \mathrm{VIII}$ \\
\hline & Columbina inca \{Lesson, 1847; & ioriolitia & TSEF/MCF & vi \\
\hline & Claravis pretiosa \{F-errar|-P $\square$ rez, 18८6\}; & palona & TSEF/MCF & $I I I, V I, V I I, V I I I$ \\
\hline & $\begin{array}{l}\text { Leptotila verreauxi Bonaparte, } 1855 \\
\text { Zentrygon albifacies Sclaier;, } 1858 \\
\text { Zenaida asiática 'LInnaeus, } 1758 \text { ' }\end{array}$ & $\begin{array}{l}\text { paloina } \\
\text { paloina } \\
\text { palona blanca / singuilott/ }\end{array}$ & $\begin{array}{l}\text { TSEF/MCF } \\
\text { TSEF/MCF } \\
\text { TSEF/MCF }\end{array}$ & 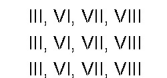 \\
\hline Tyiondae & Tyto alba (Scopoli, 1760 ) & lechuža, iecoloie lechuža / tecolott & TSEF/MCF & I, VIII, VIII, メI \\
\hline Sinigidae & Glaucidium sanchezi Lolvely \& Neluunan, 1949 & iecoloie chico / cuxcux & MCF & I, VIII, VIII, ״l \\
\hline Caprinulgıdae & $\begin{array}{l}\text { Ciccaba virgata \{Cassun, } 1849 \text {; } \\
\text { Nyctidromus albicollis }\{\text { Ginelin, } \\
\text { Antrostomus vociferus 'Wils.; }\end{array}$ & $\begin{array}{l}\text { iecoloie grande / tecolott } \\
\text { iapacanninns / poxuaca } \\
\text { iapacannins / poxuaca }\end{array}$ & $\begin{array}{l}\text { TSEF/MCF } \\
\text { MCF } \\
\text { TSEF }\end{array}$ & $\begin{array}{l}\text { I, VII, VIII, メI } \\
I, V \| I \\
I, V \| I\end{array}$ \\
\hline Trochlildae & $?$ & chuparrosas, collur $\square$ / huitzil & TSEF/MCF & I, VII \\
\hline Trogonidae & $\begin{array}{l}\text { Trogon caligatus Gould, } 1835 \\
\text { Trogon mexicanus Sivanson. } 1827\end{array}$ & 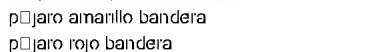 & $\begin{array}{l}\text { IMCF } \\
\text { MCF }\end{array}$ & $\begin{array}{l}\text { VIIII } \\
\text { VIII }\end{array}$ \\
\hline Monoilidae & 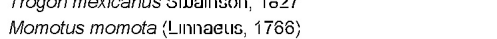 & gorrobano / motmot & TSEF/MCF & \\
\hline Alcedinindae & 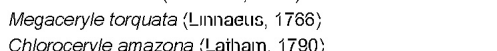 & $\begin{array}{l}\text { Inaritun pescador } \\
\text { inarīin pescador }\end{array}$ & TSEF/MCF & VIII \\
\hline \multirow[t]{2}{*}{ Rainphasiıdae } & Aulacorhynchus prasinus (Gould, 1834) & iucaneia & TSEF/MCF & I, VIIII, Xx \\
\hline & Ramphastos sulfuratus Lesson, 1830 & 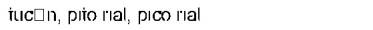 & TSEF & I, VIII, XI \\
\hline \multirow[t]{3}{*}{ Picidae } & Melanerpes aurifrons ' ('Wagler, 1829'; & P $\square$ Jaro carpiniero / cuatzurepetl & TSEF/MCF & VIII, VIIII \\
\hline & Dryocopus lineatus \{'Innnaeus, 17666 ' & $\mathrm{P \square Jarn} \mathrm{carpminiero} \mathrm{/} \mathrm{cuachenche}$ & TSEF/MCF & VIII, VIII \\
\hline & Campephilus guatemalensis ; (Harilaub, 1844; & 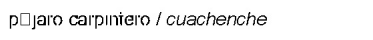 & TSEF/MCF & VII, VIII \\
\hline \multirow[t]{3}{*}{ Falconidae } & Herpetotheres cachinnans \{LInnaeus, 1758; & guactili & TSEF/MCF & $V \mid, V / I I, X I$ \\
\hline & Micrastur semitorquatus (Vielloi, 1817 ; & vaquero & TSEF/MCF & $V \mid, V / I I, X I$ \\
\hline & $\begin{array}{l}\text { Caracara cheriway (Jacquın, } 1784 \text { ) } \\
\text { Falco sparverius LInnaeus, } 1758\end{array}$ & $\begin{array}{l}\text { huatzi } \\
\text { halc } \square \text { n }\end{array}$ & $\begin{array}{l}\text { TSEF/MCF } \\
\text { TSEF }\end{array}$ & $\begin{array}{l}\text { I, VII, VII, VIII, Xl } \\
V I, V I I I, x I\end{array}$ \\
\hline \multirow[t]{4}{*}{ Psiriacidae } & Psittacara holochlorus (Sclaier, 1059) & conorritios / quilime & TSEF/MCF & $\| I I, V I, V I I, V I I I, x I$ \\
\hline & Pionus senilis $\{(\mathrm{Splx}, 1824$ ) & perico / coyo & TSEF/MCF & $\| I I, V I, V I I, V I I I, x I$ \\
\hline & Amazona viridigenalis \{Cassin, 1853 ; & perico / cutcho & TSEF & $\| I I, V I, V I I, V I I I, x \mid$ \\
\hline & Amazona autumnalis 'Lesson, 1842 ; & perico / cutcho & TSEF & $\| I I, V I, V I I, V I I I, x I$ \\
\hline Furnarindae & Xiphorhynchus sp. Sivalnson, 1827 & cuanextototl & TSEF & \\
\hline \multirow[t]{2}{*}{ Tyrannidae } & Pyrocephalus rubinus (Bocddaeti, 1783) & cardenal & TSEF/MCF & vI \\
\hline & Myiozetetes similis ‘(Splx, 1825; & & TSEF/MCF & \\
\hline \multirow[t]{2}{*}{ Corvidae } & 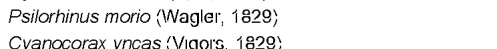 & $\begin{array}{l}\text { chichiltente } \\
\text { papán }\end{array}$ & $\begin{array}{c}\text { TSEF } \\
\text { TSEF/MCF }\end{array}$ & \\
\hline & $\begin{array}{l}\text { Cyanocorax yncas 'Vigors, 1829' } \\
\text { Convus imparatus Peiers, 1929 }\end{array}$ & $\begin{array}{l}\text { papán } \\
\text { cuervo / cacalot/ }\end{array}$ & $\begin{array}{l}\text { TSEFFMCF } \\
\text { TSEF/MCF }\end{array}$ & I, VIII, xl \\
\hline
\end{tabular}




\begin{tabular}{|c|c|}
\hline HแI'undแn่dae & Hirundo rustica !ınnaeus, 1758 \\
\hline \multirow[t]{2}{*}{ Turdidae $\{10$ ’ 5 ; } & Myadestes occidentalis Siejneger, 1882 \\
\hline & $\begin{array}{l}\text { Myadestes unicolor Sclaier, } 185 \overline{ } \\
\text { Turdus grayi Bonapalie, } 1838\end{array}$ \\
\hline Parullidae & $?$ \\
\hline \multirow[t]{2}{*}{ Icieridae } & Quiscalus mexicanus (GInel|n, 17 ○о) \\
\hline & 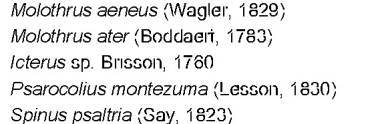 \\
\hline \multicolumn{2}{|l|}{ MAMMALIA } \\
\hline \multirow[t]{2}{*}{ Didelphidae } & $\begin{array}{l}\text { Didelphis marsupialis LInnaeus, } 1757 \\
\text { Didelphis virginiana Kerr, } 1792 \\
\text { Philander opossum \{LImnaeus, } 1758 \text {; }\end{array}$ \\
\hline & Marmosa mexicana IMelilain, $189 \overline{7}$ \\
\hline Dasypodidae & Dasypus novemcinctus !mnaeus, 1758 \\
\hline IMyıneıcophagıdae & Tamandua mexicana (de Saussure, 1800 ) \\
\hline Orden Sorlcomorpha & $?$ \\
\hline Orden Chוropiela & ? \\
\hline${ }^{\star \star A}$ Aielınae & ${ }^{\star \star}$ Ateles geoffroyi Kulhl, 1820 \\
\hline Iepolldae & Sylvilagus brasiliensis \{'-Innaeus, 1758) \\
\hline Scıulıdae & $\begin{array}{l}\text { Sciurus aureogaster (Cuv'er, 1829) } \\
\text { Sciurus deppei (Peiter's, } 1804 \text {; }\end{array}$ \\
\hline Geonyldae & Orthogeomys hispidus \{'-e Conte, 1852) \\
\hline 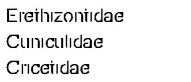 & 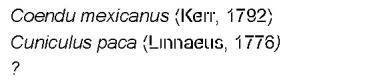 \\
\hline \multirow[t]{4}{*}{ Felidae } & Herpailurus yagouaroundi $\{(-e c \square p \square$ de, 1808$\}$ \\
\hline & 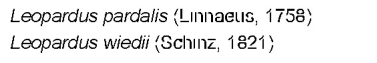 \\
\hline & Lynx rufus (Schreber; $17 \bar{T}$ ) \\
\hline & 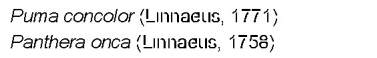 \\
\hline \multirow[t]{2}{*}{ Canıdae } & Canis latrans Say, 1823 \\
\hline & Urocyon cinereoargenteus 'Schreber, 1775) \\
\hline \multirow[t]{2}{*}{ IMephri|dae } & Conepatus leuconotus ('-Ichreensienn, 1832) \\
\hline & Mephistis macroura Lıchiensienn, 1832 \\
\hline \multirow[t]{3}{*}{ IMusielıdae } & $\begin{array}{l}\text { Spilogate gracilis IMer"rain, } 1890 \\
\text { **ontra Iongicaudis (Olfers, } 1818 \text {; }\end{array}$ \\
\hline & Eira barbara (́-1าnาaeus, 1758) \\
\hline & $\begin{array}{l}\text { Galictis vittata 'Schlıreber, } 1770 \text { ' } \\
\text { Mustela frenata Lıchiensienn, } 1831\end{array}$ \\
\hline Pincyonidae & 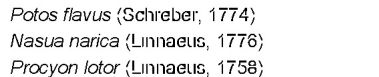 \\
\hline Tayassulae & Dicotyles angulatus (Cope, 1889) \\
\hline Celvidae & Mazama temama \{'Kerr, 1792) \\
\hline
\end{tabular}

FUNGI

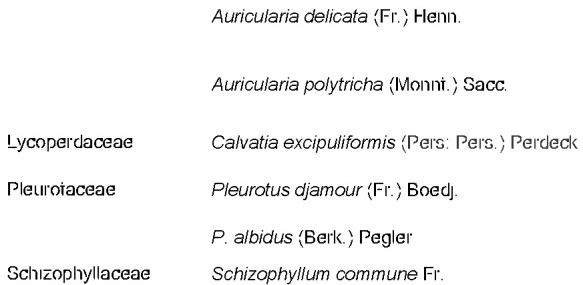

\begin{tabular}{|c|c|c|}
\hline golondrina & TSEF/MCF & \\
\hline Jilguero & TSEF/MCF & VI \\
\hline clar $\square \mathrm{n}$ & IMCF & $\mathrm{Vl}$ \\
\hline prinnavera & TSEF/MCF & $\mathrm{Vl}$ \\
\hline clıkchıı / zehualtotomet/ & TSEF/MCF & \\
\hline írdo / acatzana & TSEF/MCF & I, VII \\
\hline iordo de ojos lojos / pixpix & TSEF/MCF & I, VII \\
\hline iordo / acatzana & TSEF/MCF & I, V\|I \\
\hline calandrira, pDjaro del sol / tonaltototl & TSEF/MCF & \\
\hline pap $\square$ n real & TSEF/MCF & VIII \\
\hline donninico & TSEF/MCF & \\
\hline ìlacuache / tlacuaquilotl & TSEF/MCF & $\mathrm{III}, \mathrm{VI}, \mathrm{VII}, \mathrm{VIII}$ \\
\hline ilacuache grade / itztatlacuaquilotl & TSEF/MCF & $\mathrm{III}, \mathrm{VI}, \mathrm{VII}, \mathrm{VIII}$ \\
\hline zehuantele & TSEF/MCF & \\
\hline İä $\square$ n ilacuache / quimichitlacuaquilotl & TSEF/MCF & \\
\hline almadillo / aitoche & TSEF/MCF & I, III, VII \\
\hline oso Inieleio, oso holinıguero / xopa miel & TSEF/MCF & VIII, VIII \\
\hline เаï $\square \mathrm{n}$ / quimichi & TSEF/MCF & \\
\hline Inurcialago / calzozoth, tzotzo & TSEF/MCF & $\mathrm{I}, \mathrm{V} / \mathrm{l}$ \\
\hline * เกตาก & MCF & \\
\hline conejo / cuatochi & TSEF/MCF & $\| I I, V|, \underset{x,}{V I I}, V I I I| x$, \\
\hline ardilla, arcilla coloriada / tecomate & MCF & $\mathrm{III}, \mathrm{VI}, \mathrm{VII}, \mathrm{VIII}$ \\
\hline ardilla, ardilla negra / tecomate & TSEF/MCF & III, VI, VII, VIII \\
\hline ìuža, ìuža de ìerra, íuza raıcera / tlatituza & TSEF/MCF & $I I I, L^{x}$ \\
\hline puerco esp $\square \mathrm{n} /$ xompi & TSEF/MCF & $\| I I, V I, V I I, V I I I, x I$ \\
\hline íuža real / cuatuza, tuza rial & TSEF/MCF & $\| I I, V I, V I I, V I I I, x l$ \\
\hline laí $\square \mathrm{n} /$ quimichi & TSEF/MCF & \\
\hline onża / sacamixtle & TSEF/MCF & $V I I, V I I I, x I$ \\
\hline oceloie, leoncillo / ocelot/ & TSEF/MCF & $V I, V I I, V I I I, x I$ \\
\hline ígrillo / cuametamixto & TSEF/MCF & $I I I, V I, V I I, V I I I, x I$ \\
\hline $\begin{array}{l}\text { gaio inoni } \square \mathrm{s} \text {, gaio de inonie, gailllo / } \\
\text { coametamixto }\end{array}$ & TSEF/MCF & $V \mid, V I I, V I I I, X I$ \\
\hline $\operatorname{I} \square \mathrm{n} /$ tecuani & TSEF/MCF & $V|I I, x|$ \\
\hline ìgre / tecuaquetl, tecuani & TSEF/MCF & $V|I I, x|$ \\
\hline coyoie, perio coyoie / coyotl, coyochichi & TSEF/MCF & I, III, VII, VIII, IX, XI \\
\hline zorro / cayochi, itzcayuchi & TSEF/MCF & $I I I, V I I, V I I I, I X, x I$ \\
\hline zorrillo / epa & TSEF/MCF & $\| I I, V I I, V I I I, X I$ \\
\hline zorrillo / ера & TSEF/MCF & $I I I, V I I, V I I I, X I$ \\
\hline zorrillo / epa & TSEF/MCF & $\| I I, V I I, V I I I, X I$ \\
\hline *perro de agua / atlchich & MCF & \\
\hline perro de cerro, perro de inonie / tepechichi & TSEF/MCF & $I, V / I I, X \mid$ \\
\hline gris $\square n$ & TSEF/MCF & VIII \\
\hline 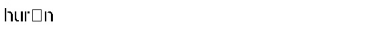 & TSEF/MCF & $\mathrm{VI}, \mathrm{VIII}$ \\
\hline Inaria / tancho & TSEF/MCF & $\| I I, V|, x|$ \\
\hline i̇ej $\square \mathrm{n}$ / pezoctle & TSEF/MCF & $I I I, V I, V I I, V I I I, x I$ \\
\hline Inapache / coaticuamizto, mapachi & TSEF/MCF & $I I I, V I, V I I I$ \\
\hline Jabal $\square$ / coapitzotl & TSEF/MCF & III, VI, VIII, „ૉ \\
\hline venado chicn / cuachacal, chacal & TSEF/MCF & $\mathrm{III}, \mathrm{VI}, \mathrm{VIII}$, 入l \\
\hline venado / mazatl & TSEF/MCF & $\| I I, V I, V I I, V I I I, x I$ \\
\hline
\end{tabular}

\begin{tabular}{|c|c|c|}
\hline $\begin{array}{l}\text { oreja, oreja de vejtia, nalga de la abuelita / } \\
\text { cuapetachiquinte, cualeleshtli }\end{array}$ & TSEF/MCF & III \\
\hline $\begin{array}{l}\text { oreja, oreja de vejtía, nalga de la abuelía / } \\
\text { cuapetachiquinte, cualeleshtil }\end{array}$ & TSEF/MCF & III \\
\hline $\begin{array}{l}\text { oreja, oreja de vejia, nalga de la abuelira / } \\
\text { cuapetachiquinte, cualeleshtil }\end{array}$ & TSEF/MCF & III \\
\hline $\begin{array}{l}\text { peloinias, huevos de venado / } \\
\text { mazattequistle, mazatinanacatl }\end{array}$ & MCF & III \\
\hline $\begin{array}{l}\text { hongo blanco / totomoshchiquinte, } \\
\text { totomoshnanacatl }\end{array}$ & TSEF/MCF & III, XX \\
\hline hongo pai $\square$ n blanco / itztacnanacat/ & TSEF/MCF & III, XII \\
\hline
\end{tabular}




\begin{tabular}{|c|c|}
\hline \multirow[t]{5}{*}{ Cantharellaceae } & Cantharellus cibarius Fr. \\
\hline & Cantharellus friessi Peck \\
\hline & Cantharellius lateritius (Berk.) SInger \\
\hline & Cantharellus lewissi \\
\hline & Cantharellus minor Peck \\
\hline Polyporaceae & Lentinus sp. $\mathrm{Fr}$. \\
\hline Usiilagınaceae & Ustilago maydis (D.C.) Corda \\
\hline \multicolumn{2}{|l|}{ PLATAE } \\
\hline Acanthaceae & Justicia spicigera Schlidil. \\
\hline Actinidlaceae & Sauravia scabrida Heınsl. \\
\hline Agavaceae & Agave sp. I. 1753 \\
\hline Alnaranihhaceae & $\begin{array}{l}\text { Amaranthus hybridus } \mathbf{L} \text {. } \\
\text { Amaranthus acanthochiton J.D. Sauer } \\
\text { Celosia cristata L. } \\
\text { Gomphrena globosa L. }\end{array}$ \\
\hline Aınary|lıdaceae & Allium glandulosum Link \& Oiin. \\
\hline \multirow[t]{2}{*}{ Anacardiaceae } & Mangifera indica $\mathrm{L}$. \\
\hline & $\begin{array}{l}\text { Spondias mombin } \mathrm{L} \\
\text { Spondias purpurea } \mathrm{L}\end{array}$ \\
\hline \multirow[t]{2}{*}{ Annonaceae } & $\begin{array}{l}\text { Annona cherimola IMIII. } \\
\text { Annona muricata } 1 .\end{array}$ \\
\hline & Rollinia membranacea Tilana \& Planch. \\
\hline Aplaceae & $\begin{array}{l}\text { Coriandrum sp. } 1 . \\
\text { Eryngium foetidum } \mathbf{L} \\
\text { Foeniculum vulgare IMIII. }\end{array}$ \\
\hline \multirow[t]{4}{*}{ Aprcylnaceae } & Allamanda sp. L. \\
\hline & Plumeria acutifolia Polrei \\
\hline & Plumeria rubra $\mathrm{L}$. \\
\hline & Stemmadenia donnell-smithii (Rose) Wonds. \\
\hline Alaceae & $\begin{array}{l}\text { Thevetia ahouai A. D.C. } \\
\text { Syngonium podophyllum Schoir. } \\
\text { Xanthosoma robustum Schoit. } \\
\text { Zantedeschia aethiopica 'L. Spreng.; }\end{array}$ \\
\hline Aralıaceae & Dendropanax arboreus (1.), Dene. \& Planch. \\
\hline Arecaceae & $\begin{array}{l}\text { Acrocomia aculeata (Jacq. ) Lodd. Ex Malt. } \\
\text { Chamaedorea elegans Mart. } \\
\text { Chamaedorea liebmannii IMalīius }\end{array}$ \\
\hline Asclepiadaceae & $\begin{array}{l}\text { Asclepias curassavica !. } \\
\text { Gonolobus niger R.BI: }\end{array}$ \\
\hline Asplenıaceae & Asplenium sphaerosporum A.R. Sin. \\
\hline \multirow[t]{3}{*}{ Asteraceae } & Achillea millefolium $\mathrm{I}$. \\
\hline & Ageratum corymbosum Zuıcc. Ex Pers. \\
\hline & 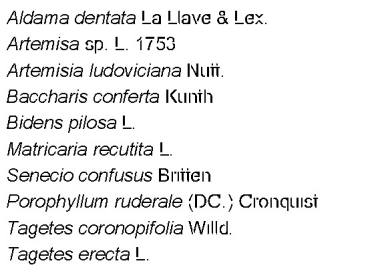 \\
\hline \multirow[t]{3}{*}{ Begonlaceae } & Begonia heracleifolia Schllidl. \& Chain. \\
\hline & Begonia nelumbijfolia Schlitul. a Chain. \\
\hline & Begonia wallichiana Lehın \\
\hline \multirow[t]{3}{*}{ Bignonaceae } & $\begin{array}{l}\text { Crescentia cujete } \mathrm{L} \text {. } \\
\text { Jacaranda mimosaefolia D. Don }\end{array}$ \\
\hline & Parmentiera aculeata ('Kuntih); Seemann \\
\hline & $\begin{array}{l}\text { Spathodea campanulata Beauv. } \\
\text { Tabebuia rosea (Beriol.; A. D. C. } \\
\text { Tecoma stans (L.); HBKK. }\end{array}$ \\
\hline \multirow[t]{2}{*}{ Bonbacaceae } & Ceiba pentandra (1-.); Gaeıt. \\
\hline & 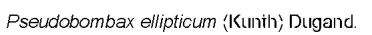 \\
\hline
\end{tabular}

\begin{tabular}{|c|c|c|}
\hline $\begin{array}{l}\text { Inongos annar|llos, anar|llo chıquinie / } \\
\text { xochilnanacatt, chipahuachiquinte, }\end{array}$ & TSEF/MCF & $I I I, x \|$ \\
\hline $\begin{array}{l}\text { Inongos ainar|llos, ainar|llo chıqu|line / } \\
\text { xochilnanacatl, chipahuachiquinte }\end{array}$ & TSEF/MCF & $I I I, x \|$ \\
\hline $\begin{array}{l}\text { Iongos annar|llos, alnar|llo chıqu|nie / } \\
\text { xochilnanacatl, chipahuachiquinte }\end{array}$ & TSEF/MCF & $\|I I, x\|$ \\
\hline $\begin{array}{l}\text { Inoradino, moradiro chiquinie / } \\
\text { xochilnanacatl, xocoyochiquinte }\end{array}$ & TSEF/MCF & $\left\|I_{1} x\right\|$ \\
\hline $\begin{array}{l}\text { Inongos annar|llos, anar|llo chıquinie / } \\
\text { xochilnanacatt, chipahuachiquinte }\end{array}$ & TSEF/MCF & $I I I, x \|$ \\
\hline tlanchinolchiquinte & TSEF & III \\
\hline $\begin{array}{l}\text { hongo de Inilpa, hongo de ına } \square \overline{\text { L }} \\
\text { cuitflacoche }\end{array}$ & TSEF/MCF & III \\
\hline mahuite, mohuite & TSEF/MCF & VII \\
\hline acalama & TSEF/MCF & \\
\hline Maguey & TSEF/MCF & \\
\hline Isnie cınarr $\square$ n & TSEF/MCF & VII \\
\hline quelite / quilitl & TSEF/MCF & III \\
\hline aเnaranio & TSEF & \\
\hline Inano de le $\square$ n & TSEF/MCF & $I, V / I I, x \mid$ \\
\hline diente de le $\square \mathrm{n}$ & TSEF/MCF & I, VIII, Xl \\
\hline cebolleja / xonacate, xonacatl & TSEF/MCF & $\| I I, V I I, x$ \\
\hline $\begin{array}{l}\text { Inango croollo, Inango Inanla, Inango } \\
\text { peiac } \square \text { n }\end{array}$ & TSEF/MCF & $\|I\| I,, V\|\| I, x, x \mid$ \\
\hline jobo / cuaxocotl & TSEF/MCF & $\|\| I I,, V \|, x, x \mid$ \\
\hline Ciruela & TSEF/MCF & $\|\| I,\|, V\|, x, x \mid$ \\
\hline anกaาa & TSEF/MCF & II, III, V, XI \\
\hline guanabana & TSEF & $I I, I I I, V, X I$ \\
\hline anona & TSEF & $\|\| I, V,, X l$ \\
\hline Clantio / colantro & TSEF/MCF & $\| I I, X \mid$ \\
\hline Clantiro extranjero / viscolantro & TSEF/MCF & $\| I I, x \mid$ \\
\hline |าเทาดอ & TSEF/MCF & $\| I I, V I I, X \mid$ \\
\hline copa de oro, copa de rey & TSEF/MCF & VIIII \\
\hline $\begin{array}{l}\text { flor de inayo, flor de la cluz / } \\
\text { cacalotlxuchitl }\end{array}$ & TSEF/MCF & $I, \| I, V I I, V \mid I I, x I$ \\
\hline $\begin{array}{l}\text { flor de Inayo, flor de la ciūu / } \\
\text { cacalottxuchitl }\end{array}$ & TSEF/MCF & $I, \| I, V I I, V I I I, x I$ \\
\hline coj $\square$ n de gaís & TSEF/MCF & $V I I, x I$ \\
\hline huevos de ioro & TSEF & VIII, VIII \\
\hline chapis & TSEF/MCF & VIII, VIII \\
\hline hoja de luna / quequeshquilitt & TSEF/MCF & III, VIII \\
\hline alcailaž & $\mathrm{MCF}$ & $I, V / I I I, x \mid$ \\
\hline tamalcohuitl & TSEF/MCF & $\mathrm{II}, \mathrm{IV}, \mathrm{V}, \mathrm{XI}$ \\
\hline coyol & TSEF & $|I I, X|$ \\
\hline palınılla & TSEF & $I, V / I I, x \mid$ \\
\hline palınılla & $\mathrm{MCF}$ & $|, V| I I, x \mid$ \\
\hline venenıllo, quiebra inuelas & TSEF/MCF & VII \\
\hline apayoie / cuahuayote & TSEF/MCF & \\
\hline pesina chico, pesinira & $\mathrm{MCF}$ & \\
\hline plunnajllo & MCF & VIII, VIII \\
\hline hier'ba del pasıno & MCF & VIII, VIII \\
\hline acahual & TSEF/MCF & $x$ \\
\hline ajenјం & TSEF/MCF & VII \\
\hline esiańlaie & $\mathrm{MCF}$ & VII \\
\hline escobilla / tepetlapushtle & TSEF/MCF & ${ }^{x}$ \\
\hline mozotl & TSEF/MCF & ${ }^{x}$ \\
\hline Inalnżanıılla & TSEF/MCF & $V I I, x_{I}$ \\
\hline पrinıca & TSEF/MCF & VII \\
\hline papalo quelite & TSEF/MCF & $\| I I, X \mid$ \\
\hline ceinpoal sllvestire / cempoalxuchitl & TSEF/MCF & I \\
\hline ceinpoal / cempoalxuchit/ & TSEF/MCF & I, VIII, VIIII, XI \\
\hline doncella / mayahual & IMCF & \\
\hline bandejita / mayahual del meco & MCF & \\
\hline xihuite amargoso & MCF & \\
\hline ilıno / cuatecomate, cuatecomactli & TSEF/MCF & x \\
\hline jacaranda & TSEF/MCF & VIII \\
\hline choie & TSEF/MCF & $\|\| I I,, V \|$ \\
\hline San Josexuchiṅ| & TSEF/MCF & I, V/III \\
\hline palo de rosa & TSEF & II, VIII \\
\hline ahuexuchicera & TSEF/MCF & \\
\hline ceiba & TSEF/MCF & $\mathrm{II}, \mathrm{IV}, \mathrm{V}, \mathrm{XI}$ \\
\hline cabello de Dngel / tzotzocole & TSEF & $\|\| V,, V\|\|$ \\
\hline
\end{tabular}




\begin{tabular}{|c|c|c|c|c|}
\hline Blassicaceae & $\begin{array}{l}\text { Brassica aff. Oleracea I. } \\
\text { Aechmea bracteata (Sil.) Griseb. }\end{array}$ & $\begin{array}{l}\text { quelite de } \mathrm{col} / \text { colquilitl } \\
\text { amoxco, tecolometl }\end{array}$ & $\begin{array}{l}\text { TSEF/MCF } \\
\text { TSEF }\end{array}$ & III \\
\hline \multirow[t]{3}{*}{ Binneliaceae } & Ananas comosus 1 . Merr. & pı $\square$ a & TSEF/MCF & III \\
\hline & Tillandsia recurvata (1.), L. 1762 & İ॥nbıliche & TSEF/MCF & \\
\hline & Tillandsia usneoides. 'L.; 1. & heno & MCF & I, VIIII \\
\hline \multirow[t]{3}{*}{ Burseraceae } & Bursera penicillata (Sess $\square$ \& IMoc.) ex DC. Engel & palo brujo & TSEF & II, IV \\
\hline & Bursera simaruba (1.); Sarg. & chaca & TSEF/MCF & $\|, I V, V\|$ \\
\hline & Protium copal (Schlidl. \& Chaın. ; Engl. & copal & TSEF/MCF & $I, \| I, I V, x, x I$ \\
\hline \multirow[t]{4}{*}{ Caciaceae } & Acanthocereus sp. (Engelm ex. A Berger; Brition \& Rose & lanna-nopal / jacube & TSEF/MCF & $|I I, X|$ \\
\hline & Hylocereus undatus \{'Halu.; Brin̈on \& Rose & piraya & TSEF/MCF & $|I I, x|$ \\
\hline & Opuntia streptacantha Ieln. & nopal & TSEF/MCF & $|I I, x|$ \\
\hline & $?$ & অrgano & TSEF & VII \\
\hline Caprifollace & Sambucus mexicana Presl. & sauco & MCF & $\|, x$ \\
\hline \multirow{2}{*}{ Carlcaceae } & Carica cauliffora Jacq. & ochonite, ochonictli & TSEF/MCF & III \\
\hline & Carica papaya L. & рарауа & TSEF/MCF & $|I I, x|$ \\
\hline Cecroplaceae & Cecropia obtusifolia Beitol. & $\begin{array}{l}\text { palo de canal, palo chifil } \square \text { n, horıniguillo/ } \\
\text { cuaquiquistli }\end{array}$ & TSEF/MCF & $\| \mathrm{II}, \mathrm{V}, \mathrm{VII}$ \\
\hline Chenopodlaceae & Chenopodium ambrosioides $\mathrm{L}$. & epaz̄oie / epazoctli & TSEF/MCF & $\| I I, V I I, x l$ \\
\hline \multirow[t]{2}{*}{ Cleithraceae } & Clethra mexicana DC. & aguacailllo & MCF & \\
\hline & Clethra pringlei $\mathrm{S}$. Waison & aguacailllo & MCF & \\
\hline Combreiaceae & Terminalia catappa $\mathrm{L}$. & alinendio & TSEF/MCF & $\| I_{1} V I I I, x$ \\
\hline \multirow[t]{3}{*}{ Convolvulaceae } & Ipomoea batatas Laın. & calnoie & TSEF/MCF & $|I I, x|$ \\
\hline & Ipomea purga ('Nender:'; Hayne & zoyo & TSEF/MCF & III \\
\hline & Ipomoea sp. Sendih. Ex. Vell. & bejuco de flores azules, quiebra plaios & TSEF/MCF & \\
\hline Clasulaceae & Kalanchoe pinnata (Lamarck) Persoon & ì|onadora & TSEF/MCF & x \\
\hline \multirow[t]{3}{*}{ Cucubiaceae } & $\begin{array}{l}\text { Citrullus lanatus } \\
\text { (Thullu.) I Maisuln. \& Nakal } 1910\end{array}$ & sand $\square a$ & TSEF & $|I I, x|$ \\
\hline & Cucurbita maxima Lan. & calabaz̄a & TSEF/MCF & $|I I, x|$ \\
\hline & Sechium edule (Jacq.) Siw. & chayoie & TSEF/MCF & $|I I, x|$ \\
\hline Chrysobalanaceae & Couepia polyandra '́(Kuni|h) Rose & olopillo & TSEF & \\
\hline Cyailheaceae & Cyathea fulva \{'M. Maireens \& Galeoni்!) & pesina grande & MCF & VII \\
\hline Cyperaceae & Cyperus odoratus $\mathrm{L}$. & zacaie & TSEF/MCF & $x^{x}$ \\
\hline Ebenaceae & Diospyros digyna Jacq. PI. høit. schneenbr & zapoie negro / zapot! & TSEF/MCF & $I I I, x, x$ \\
\hline \multirow[t]{8}{*}{ Euphorblaceae } & Cnidoscolus aconitifolius ('MIII.) I. M. Johnsi. & chaya / chichacuahuitl & TSEF/MCF & \\
\hline & Cnidoscolus multilobus ‘ $\mathrm{Pax}$ ’ I.IM. Johnsi. & tesonquilit! & TSEF/MCF & \\
\hline & Croton draco Sclolidl. & sangregado / escuahuitl & TSEF/MCF & $\|, \mathrm{VII}$ \\
\hline & Croton pulcher IM III. Arg. & solinali & TSEF/MCF & \\
\hline & Euphorbia pulcherrima Willd. ex Kloiżsch & $\begin{array}{l}\text { filor de la virgen, noche buena / } \\
\text { tonantzinxiuhuitl }\end{array}$ & TSEF/MCF & I, VIII, XI \\
\hline & Jatropha curcas L. 1753 & pigun & TSEF/MCF & ॥ \\
\hline & Manihot esculenta Cranīiz & yuca & TSEF/MCF & $|I I, x|$ \\
\hline & Ricinum communis $\mathrm{I}$. & higuerilla & TSEF/MCF & \\
\hline Equсceiaceae & Equisetum sp. 1. & cola de caballo / aquiztopile & TSEF/MCF & III \\
\hline \multirow[t]{24}{*}{ Fabaceae } & Acacia cornigera L. Willd. & ioro cuerno & TSEF/MCF & ॥ \\
\hline & Acosmium panamense (Benth.; Y'yakovlev & hueso de ìgre, huesillo & TSEF & II, IV \\
\hline & Amicia zygomeris DC. & papaloxihuitl & TSEF & \\
\hline & Arachis hypogaea & cacaluaie & TSEF/MCF & III \\
\hline & Bauhinia divaricata $\mathrm{L}$. & paia de buey & TSEF & $\| I, I V, V I I I$ \\
\hline & Caesalpinia pulcherrima Bentilh. & 口rbol de rosal / tabachín & TSEF/MCF & VIIII \\
\hline & Cajanus cajan (1-) Millsp. & leniej|lla, frijol grande & TSEF/MCF & III \\
\hline & Cassia fistula $\_$. & lluva de oro & TSEF/MCF & $I I, I V, V I I I$ \\
\hline & 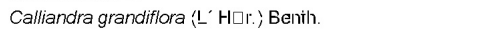 & cabello de $\square$ ngel / tzotzocole & TSEF/MCF & \\
\hline & 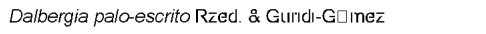 & palo escriro & TSEF/MCF & $|V, V, x|$ \\
\hline & Delonix regia (Bojer) Raf. & 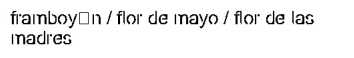 & TSEF/MCF & II, IV, VIII \\
\hline & Diphysa senoides Bentih. & quiebra hacha / quebrache, quebrachi & TSEF/MCF & IV,$V$ \\
\hline & Erythrina americana IMIII. & peinuche / pemuch & TSEF/MCF & $\| I, I I I, I V, V / I, \mid X$ \\
\hline & Erythrina lanata Rose & peinuche / pemuch & TSEF/MCF & II, IV, VII, IX \\
\hline & Eysenhardtia platycarpa Pennell \& Saíf. & palo azuul & TSEF & VII \\
\hline & Cliricidia sepium (Jacq.) Sieud. & cacahuitl & TSEF & \\
\hline & Mucuna pruriens \{-..; DC. & pica pica & TSEF/MCF & \\
\hline & Phaseolus coccineus I. & frijol & TSEF/MCF & $|I I, x|$ \\
\hline & Phaseolus sp. L. & cashtilán & TSEF/MCF & III \\
\hline & Piscidia piscipula (1..) Sarg. & chإרוס & TSEF & \\
\hline & Pithecellobium dulce (Roxb.) Bentil). & ז́"yolullo / hunn & TSEF/MCF & $|I I, x|$ \\
\hline & Tamarindus indica $\mathrm{L}$. & tianar"lndo / tamarindocuahuitl & TSEF/MCF & II, III, IV, XI \\
\hline & Trifolium sp. 1. & quelite estiella & TSEF/MCF & \\
\hline & Vicia faba $\mathrm{L}$ & haba & TSEF/MCF & $|I I, x|$ \\
\hline \multirow[t]{5}{*}{ Fagaceae } & Quercus affinis Scheidin. & encino / tiocuahuitl & MCF & $\|,|V, V, x|$ \\
\hline & Quercus ocoteaefolia Liebın. & encmo / tiocuahuitl & MCF & $\| I, I V, V, x I$ \\
\hline & Quercur oleoides Chain \& Schlidd. & encino / tiocuahuitl & TSEF & $I I, I V, V, x I$ \\
\hline & Quercus sartorii $\mathrm{N} \square$ e & encmo / tiocuahuitl & MCF & $\| I, I V, V, x I$ \\
\hline & Quercus xalapensis Hlunb. \& Bonpl. & encino / tiocuahuitl & MCF & $\| I,|V, V, x|$ \\
\hline
\end{tabular}




\begin{tabular}{|c|c|}
\hline Granıneae & Lasiacis divaricata (-); A S. Hlich. \\
\hline Haıneinelidaceae & Liquidambar macrophylla Oelsi. \\
\hline \multirow[t]{2}{*}{ Heliconlaceae } & Heliconia collinsiana Griggs. \\
\hline & Heliconia schideana Kloiżsch. \\
\hline \multirow[t]{11}{*}{ Lamıaceae } & 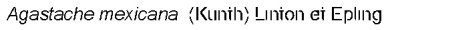 \\
\hline & Clerodendrum thomsoniae Balf. \\
\hline & Mentha spicata I. \\
\hline & Ocimum basilicum 1. \\
\hline & Origanum mejorana $\mathrm{L}$. \\
\hline & Origanum vulgare $\mathrm{L}$. \\
\hline & Rosmarinus officinalis $!$. \\
\hline & Salvia leucantha Cav. \\
\hline & Salvia mexicana $\mathrm{L}$. \\
\hline & Sesamum indicum $\mathbf{L}$. \\
\hline & Stachys parvifolia IMariens \& Galenї̈ \\
\hline \multirow[t]{6}{*}{ Laulraceae } & Cinnamomum camphora $\mathrm{L}$. \\
\hline & Cinnamomum verum J. Presl \\
\hline & Licaria capitata (Chain. \& Schdì.) ' Kosierin. \\
\hline & Persea americana IMIIler \\
\hline & $\begin{array}{l}\text { Persea americana var. drymifolia (Schlıl. \& Chain.) S. F. } \\
\text { Blake }\end{array}$ \\
\hline & Persea schiedeana Nees \\
\hline Lillaceae & Allium sativum $\mathbf{L}$. \\
\hline Lophosorlaceae & Lophosoria quadripinnata (J. F. Ginel.) C. Chr. \\
\hline Lolanthaceae & Struthanthus crassipes (Olver) Eıchler \\
\hline \multirow{2}{*}{ IVagnoliaceae } & Magnolia grandifolia L. \\
\hline & Talauma mexicana (DC.; Don \\
\hline \multirow[t]{2}{*}{ IMalpıghıaceae } & Bunchosia palmeri S. Waison \\
\hline & Byrsonima crassifolia \{L., Kunท่|? \\
\hline \multirow[t]{4}{*}{ IValvaceae } & Hibiscus rosa-sinensis !. \\
\hline & Hibiscus sabdariffa $\mathrm{L}$. \\
\hline & Malvaviscus arboreus Cav. \\
\hline & Quararibea funebris \{-a Llave; VIscher \\
\hline \multirow[t]{2}{*}{ Melasionaiaceae } & Conostegia xalapensis (Bonpl.); D. Don ex DC. \\
\hline & Arthrostemma ciliatum Pav. ex D. Don \\
\hline \multirow[t]{5}{*}{ Mellaceae } & Azadirachta indica A. Juss. \\
\hline & Cedrela odorata L. \\
\hline & Guarea glabra Valıl \\
\hline & Melia azedarach $\mathrm{L}$. \\
\hline & Swietenia macrophylla Kıng \\
\hline \multirow[t]{2}{*}{ Menısperinaceae } & Cissampelos owariensis Beauvais ex DC. \\
\hline & 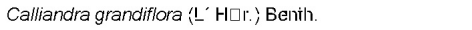 \\
\hline \multirow[t]{2}{*}{ IMınosaceae } & Inga jinicuil Schlitul. a Chain. Ex G. Don \\
\hline & Inga vera Willd. \\
\hline \multirow[t]{4}{*}{ IMoraceae } & Brosimum alicastrum SiJ. \\
\hline & Castilla elastica Celv. \\
\hline & Ficus padifolia H.B.K. \\
\hline & Maclura tinctoria \{L-.; D. Don ex Gieud \\
\hline IMuni่inglaceae & Muntingia calabura $\mathrm{L}$. \\
\hline \multirow[t]{2}{*}{ IMusaceae } & Musa paradisiaca !. \\
\hline & Musa balbisiana Colla \\
\hline Myrsinaceae & Myrica cerifera $\mathrm{L}$. \\
\hline & Eucapyotus sp. 1. Her. \\
\hline Myrsinaceae & Stylogyne sp. A. DC. \\
\hline IMyıíaceae & Eugenia capuli ‘Chain. \& Sch|dl.; O. Berg \\
\hline & Pimenta dioica (1.). Merr. \\
\hline & Psidium guajava $\mathrm{L}$. \\
\hline Mıciagynaceae & Bougainvillea glabra Cholsy \\
\hline Onagraceae & Fuchsia microphylla Kunti'? \\
\hline Michıdaceae & Oncidium sphacelatum Lindl. \\
\hline & Vanilla planifolia Jacks. \\
\hline Oxalıdaceae & Averrhoa carambola $\mathrm{L}$ \\
\hline PInaceae & Pinus greggï Engleın. \\
\hline & Pinus patula Schlechì ei Chain. \\
\hline Pipelaceae & Piper auritum Kuntih \\
\hline & Peperomia sp. Ruız a Pav. \\
\hline Plaianaceae & Platanus mexicana Moric. \\
\hline Poaceae & Arundo donax $\mathrm{L}$. \\
\hline & Echinochloa colona (1-.) ' LInk \\
\hline & Digitaria decumbens Sient. \\
\hline & Guadua amplexifolia J.Presl \\
\hline & Pennisetum purpureum Schunnach. \\
\hline & Saccharum officinarum 1 . \\
\hline
\end{tabular}

\begin{tabular}{|c|c|c|}
\hline bainb $\square$ & TSEF & $\|, I V$ \\
\hline suclıaie / suchiatl & TSEF/MCF & $I_{1}, \mathrm{IV}$ \\
\hline papatla & IMCF & III, VIII \\
\hline papatla & TSEF & III, VIII \\
\hline ioronנll & MCF & VII \\
\hline velo de novia & TSEF & VIII, IX \\
\hline herba buena & TSEF/MCF & $\mathrm{VII}$ \\
\hline albahaca & TSEF/MCF & $\mathrm{I}, \| I \mathrm{I}, \mathrm{VII}$ \\
\hline inejorana & TSEF/MCF & VII \\
\hline পr $\square$ gano & TSEF/MCF & $I I I, V I I, x \mid$ \\
\hline ronero & TSEF/MCF & I, VII \\
\hline cordoncillo & IMCF & \\
\hline tlanchichinole & IMCF & \\
\hline aృ에이미 & TSEF/MCF & $|I I, x|$ \\
\hline talachia & IMCF & \\
\hline alcaníor & TSEF/MCF & VII \\
\hline canela & TSEF/MCF & III \\
\hline xollime & IMCF & \\
\hline aguacaie / aguacat/ & TSEF/MCF & $\|I\| I,, I V, V|I, x, x|$ \\
\hline aguacaie oloroso / aguacatl tlapanilli & TSEF/MCF & $\|I\| I,, I V, V \|, \asymp, x \mid$ \\
\hline pahuı / pahuatl & TSEF/MCF & $\|I\|,\|V, V\|, \times, x \mid$ \\
\hline ajo & TSEF/MCF & $I I I, V / I$ \\
\hline pesina & IMCF & \\
\hline seca palo & TSEF/MCF & \\
\hline Inagnolia & TSEF & VIII \\
\hline yoloxuchitl & TSEF & VII, VIIII \\
\hline huasha & TSEF/MCF & \\
\hline nantzi & TSEF & II, III, ג I \\
\hline íulip $\square n$ & TSEF/MCF & VIIII \\
\hline jannaca & TSEF/MCF & III, VII, ג XI \\
\hline Inanาżanı่̇a & TSEF/MCF & VIII \\
\hline cacahuaxochitl & TSEF/MCF & \\
\hline teshua & MCF & \\
\hline quelite agrio / xocoquilitl & TSEF/MCF & III \\
\hline רור & TSEF & \\
\hline cedin, cedin Iojo / tiocuahuitl & TSEF/MCF & $|V, V, x|$ \\
\hline palo blanco / itztaccuahuitl & TSEF & \\
\hline pioche, pıochı & TSEF/MCF & $\mathrm{II}_{\mathrm{i}} \mathrm{IV}$ \\
\hline canba & TSEF/MCF & $|V, V, X|$ \\
\hline cintzo & MCF & \\
\hline cabello de $\square$ ngel / tzotzocole & TSEF/MCF & VIII \\
\hline chalahuire / chalahuixtli & TSEF/MCF & II, IV \\
\hline chalahuire / chalahuixtli & TSEF/MCF & II. IV \\
\hline ojite & TSEF/MCF & \\
\hline palo de hule / olicuahuitl & TSEF & IV \\
\hline jalaınaie / xalamatl & TSEF/MCF & \\
\hline inora & TSEF/MCF & $\mathrm{II}, \mathrm{IV}, \mathrm{V}$ \\
\hline capul $\square$ n pujhua & TSEF & III \\
\hline pl $\square$ iano & TSEF/MCF & $|I I, x|$ \\
\hline platiano Inacho & TSEF/MCF & $|I I, x|$ \\
\hline ahuaxochitl & IMCF & \\
\hline elicalipio & MCF & \\
\hline capul $\square$ n / capolin & TSEF & III \\
\hline pisie & TSEF & \\
\hline pוnıenia & TSEF/MCF & $\|\| I I,, I V, V, X, X I$ \\
\hline guayaba / chalchocotl & TSEF/MCF & II, III, VII, メ, xl \\
\hline bugainbilla & TSEF/MCF & VIII \\
\hline aleilllo & TSEF/MCF & \\
\hline $\begin{array}{l}\text { flor de la salnia cruze, flor de inayo, flor de } \\
\text { cularesina }\end{array}$ & TSEF/MCF & I, VIIII \\
\hline valnilla & TSEF & $I I I, V I I I, x l$ \\
\hline caraınbola & TSEF & $|I I, X|$ \\
\hline po & IMCF & II, IV \\
\hline po & IMCF & $\mathrm{II}_{\mathrm{I}} \mathrm{IV}$ \\
\hline iequelire / acoyo, tequequilit/ & TSEF/MCF & III \\
\hline verdolaga de inolie & TSEF/MCF & III \\
\hline Glaino / acuahuit/ & TSEF & $\|, I^{2}$ \\
\hline carlitzo & TSEF/MCF & $I_{1} I^{2}$ \\
\hline zacaie cololado & TSEF/MCF & Ix \\
\hline pasto paingola & TSEF/MCF & Ix \\
\hline otate & TSEF/MCF & $I_{1}, I_{1} I_{x}$ \\
\hline pasio iallu $\square \mathrm{n}$ & TSEF/MCF & $x^{x}$ \\
\hline ca $\square$ a de az̄ $\square$ cal' & TSEF/MCF & $I I, I I I,|x, x|$ \\
\hline
\end{tabular}




\begin{tabular}{|c|c|c|c|c|}
\hline Polypodiaceae & Phlebodium aureum \{L.; J. Similh & cosillla de le $\square \mathrm{n}$ / tehuancachiticuahuitl & MCF & \\
\hline & Rumex sp. 1. & lengua de vaca & TSEF/MCF & III \\
\hline Pieridaceae & Adiantum sp. !. & pesinita & TSEF/MCF & \\
\hline Rhaınnaceae & Karwinskia humboldtiana (Roeıner \& Schulies); Zuucc. & capul $\square$ n de zorra, capul $\square$ n cınarr $\square$ n & TSEF & III \\
\hline \multirow[t]{3}{*}{ Rosaceae } & Eriobotrya japonica (Thunb.) LIndl. & $\mathrm{n} \square$ spero, $\mathrm{n \square} \square$ sfero & MCF & III \\
\hline & Prunus persica (1..); Baisch. & durażno & TSEF/MCF & III \\
\hline & Prunus serótina Ehrih. & capul $\square$ n & TSEF/MCF & III \\
\hline \multirow[t]{3}{*}{ Rublaceae } & Coffea arabica 1. & саі́ロ & TSEF/MCF & $I I I, V I I,|X, x|$ \\
\hline & Hamelia patens Jacq. & Inaduro zapoie / cacahuaxochitl & TSEF/MCF & $\mathrm{VII}$ \\
\hline & Galium mexicanum Kunth & pegarropa & MCF & \\
\hline \multirow[t]{9}{*}{ Rเìaceae } & Casimiroa edulis Llave \& $\mathrm{L} e x$. & zapoie blanco / iztaczapot/ & TSEF & \\
\hline & Citrus aurantifolia (Chr|sinn.) SIDIngle & naranja cınarrona & TSEF/MCF & III \\
\hline & Ciritus $\square$ sınensis Osbeck & naranja & TSEF/MCF & III, $|x, x|$ \\
\hline & Citrus limetta Risso & IIna & TSEF/MCF & III \\
\hline & Citrus maxima (Burın. ex Ruınph.; Merr. & $\operatorname{lin} \square n$ & TSEF/MCF & $I I I, V I I, X I$ \\
\hline & Citrus reticulata Blanco & Inandarima & TSEF/MCF & $I I I,|x, x|$ \\
\hline & Citrus $\times$ paradisi Macfad. & ímonja & TSEF/MCF & III \\
\hline & Murraya paniculata Joknennng $E \times 1$. & Iınonalia & TSEF & VIII \\
\hline & Ruta chalepensis !. & ruda & TSEF/MCF & VII \\
\hline \multirow[t]{2}{*}{ Salıcacaea } & Salix humboldtiana Willd. & saluce & TSEF & $x$ \\
\hline & Zuelania guidonia \{Siy.) Briñ. \& Millsp. & volar $\square n$ & TSEF & 1 \\
\hline \multirow[t]{2}{*}{ Sapmndaceae } & Litchi chinensis Soln?. & IIchı & TSEF/MCF & $|I I, X|$ \\
\hline & Sapindus saponaria 1. & jaboncion & TSEF & Ix \\
\hline \multirow[t]{3}{*}{ Sapoiaceae } & Manilkara zapota (1.). valn Royen & clıcozapoie / xicotizapot/ & TSEF/MCF & $I I, I I I, X, X I$ \\
\hline & Pouteria campechiana \{'Kunih); Baelıı! & żapoie aınarillo & TSEF/MCF & III \\
\hline & Pouteria sapota (Jaç.) H.E. Moore \& Siealn. & zapoie Inaıney / zapotl & TSEF/MCF & $\| I, I I I,|V, V| I, x, x \mid$ \\
\hline Sınaroubaceae & Simarouba glauca DC. & plstache & TSEF & $I_{1} \mathrm{IV}$ \\
\hline \multirow[t]{6}{*}{ Solanaceae } & Capsicum annuum $\mathbf{L}$. & chuliep $\square$ n & TSEF/MCF & III \\
\hline & Capsicum sp. 1. & chule & TSEF/MCF & III \\
\hline & Brugmansia $\square$ candida Pers. & xochilcampana & TSEF/MCF & $\mathrm{V} / \mathrm{II}, \mathrm{VIII}$ \\
\hline & Nectandra sanguínea Roïb. & aguacachile & TSEF/MCF & \\
\hline & Nicotiana tabacum $!$. & íabaco & TSEF/MCF & $I, V I I,|x, x|$ \\
\hline & Solanum nigrescens IVait. \& Gal. & iomailllo & TSEF/MCF & $|I I, X|$ \\
\hline \multirow[t]{2}{*}{ Siercullaceae } & Guazuma ulmifolia Lain. & guasına / aquiche & TSEF/MCF & $\|$ \\
\hline & Theobroma cacao !. & cacao & TSEF & III, VIII \\
\hline Tillaceae & Heliocarpus donnell-smithii Rose & jonoie & TSEF/MCF & $x$ \\
\hline \multirow[t]{3}{*}{ Ulinaceae } & Aphananthe monoica (Hleinsl.) J.F. Leroy & ajuate, ajuactii & TSEF & \\
\hline & Ulmus mexicana (Llebın.) Planch. & palo var $\square$ n, palo de hoinbre / tlacacuahuitl & TSEF/MCF & IV V V \\
\hline & Trema micrantha (1-); Blune & gunnda, capolan & TSEF & III \\
\hline \multirow[t]{2}{*}{ Ulìicaceae } & Urera caracasana (Jacq.) G Giseb. & oт̇iga real & TSEF/MCF & VII \\
\hline & Urtica mexicana Lıeınb. & ஃїіga & TSEF/MCF & VII \\
\hline Verbenaceae & Petrea volubilis $L$. & raspasoinble'o & TSEF/MCF & $\|, I I I, V I I, V I I I$ \\
\hline V/i̇aceae & Vitis tilififolia Huınb. \& Bonpl. ex Rneın. \& Schult. & Inecaie de inva / cuaxocomecatl & TSEF/MCF & III \\
\hline Zalniaceae & Zamia herrerae Calder $\square n$ \& Siandl. & zoInpollo & TSEF/MCF & \\
\hline \multirow[t]{2}{*}{ Z̄ingiberaceae } & Costus mexicanus Lıebın. & $\begin{array}{l}\text { ca } \square \text { a de jabal } \square \text { / cuapitzoatl, } \\
\text { acatlcuapitzxihuitl }\end{array}$ & TSEF/MCF & VII \\
\hline & Zingiber officinale ('-) Roscose. & jengibre & TSEF/MCF & III, VIII, XI \\
\hline
\end{tabular}

